\title{
Materials Technology Assessment for a 1050 K Stirling Space Engine Design
}

Coulson M. Scheuermann, Robert L. Dreshfield, Darrell J. Gaydosh, James D. Kiser, Rebecca A. MacKay, David L. McDanels, Donald W. Petrasek, Raymond D. Vannucci, Kenneth J. Bowles and Gordon K. Watson Lewis Research Center

Cleveland, Ohio

\section{DISCLAIMER}

This report was prepared as an account of work sponsored by an agency of the United States Government. Neither the United States Government nor any agency thereof, nor any of their employees, makes any warranty, express or implied, or assumes any legal liability or responsibility for the accuracy, completeness, or usefulness of any information, apparatus, product, or process disclosed, or represents that its use would not infringe privately owned rights. Reference herein to any specific commercial product, process, or service by trade name, trademark, manufacturer, or otherwise does not necessarily constitute or imply its endorsement, recommendation, or favoring by the United States Government or any agency thereof. The views and opinions of authors expressed herein do not necessarily state or reflect those of the United States Government or any agency thereof.

\section{NMs}




\section{DISCLAIMER}

This report was prepared as an account of work sponsored by an agency of the United States Government. Neither the United States Government nor any agency Thereof, nor any of their employees, makes any warranty, express or implied, or assumes any legal liability or responsibility for the accuracy, completeness, or usefulness of any information, apparatus, product, or process disclosed, or represents that its use would not infringe privately owned rights. Reference herein to any specific commercial product, process, or service by trade name, trademark, manufacturer, or otherwise does not necessarily constitute or imply its endorsement, recommendation, or favoring by the United States Government or any agency thereof. The views and opinions of authors expressed herein do not necessarily state or reflect those of the United States Government or any agency thereof. 


\section{DISCLAIMER}

Portions of this document may be illegible in electronic image products. Images are produced from the best available original document. 


\title{
Materials Technology Assessment for a 1050 K Stirling Space Engine Design
}

\author{
Coulson M. Scheuermann, Robert L. Dreshfield, Darrell J. Gaydosh, \\ James D. Kiser, Rebecca A. MacKay, David L. McDanels, \\ Donald W. Petrasek, Raymond D. Vannucci, \\ Kenneth J. Bowles and Gordon K. Watson \\ Lewis Research Center \\ Cleveland, Ohio
}

\section{DISCLAIMER}

October 1988

This report was prepared as an account of work sponsored by an agency of the United States Government. Neither the United States Government nor any agency thereof, nor any of their employees, makes any warranty, express or implied, or assumes any legal liability or responsibility for the accuracy, completeness, or usefulness of any information, apparatus, product, or process disclosed, or represents that its use would not infringe privately owned rights. Reference herein to any specific commercial product, process, or service by trade name, trademark, manufacturer, or otherwise does not necessarily constitute or imply its endorsement, recommendation, or favoring by the United States Government or any agency thereof. The views and opinions of authors expressed herein do not necessarily state or reflect those of the United States Government or any agency thereof.

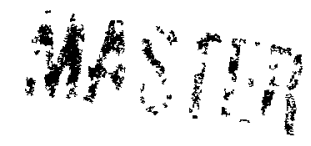




\title{
MATERIALS TECHNOLOGY ASSESSMENT FOR A $1050 \mathrm{~K}$ STIRLING SPACE ENGINE DESIGN
}

\author{
Coulson M. Scheuermann, Robert L. Dreshfield, Darrell J. Gaydosh, \\ James D. Kiser, Rebecca A. MacKay, David L. McDanels, \\ Donald W. Petrasek, Raymond D. Vannucci, \\ Kenneth J. Bowles, and Gordon K. Watson \\ National Aeronautics and Space Administration \\ Lewis Research Center \\ Cleveland, Ohio 44135
}

\begin{abstract}
SUMMARY
An assessment of materials technology and proposed materials selection was made for the $1050 \mathrm{~K}$ (superalloy) Stirling Space Engine design. The objectives of this assessment were to evaluate previously proposed materials selections, evaluate the current state-of-the-art materials, propose potential alternate materials selections and identify research and development efforts needed to provide materials that can meet the stringent system requirements. This assessment generally reaffirmed the choices made by the contractor; however, in many cases alternative choices were described and suggestions for needed materials and fabrication research and development were made.
\end{abstract}

\section{INTRODUCTION}

The Stirling engine is under development for a feasibility demonstration of its potential use as a space auxiliary power source (ref. 1). This engine offers several potential advantages: high system efficiency, low specific weight, low vibration amplitude, and long life (ref. 2).

Sunpower, Inc., of Athens, Ohio, was awarded a contract in May 1984 to design a Stirling engine for space applications. The contract was modified in January 1986 to include an engine design using superalloys and having a design operating temperature of $1050 \mathrm{~K}$ over a system life of $60000 \mathrm{hr}$. The materials selections for this superalloy design are the subject of this assessment. Materials selections for various portions of the engine were recommended by the contractor (ref. 3). A team of materials specialists from the NASA Lewis Research Center Materials Division was assembled to assess the proposed materials selections and the state-of-the art materials technology, to propose potential alternate selections and to identify research and development efforts needed to provide materials that could meet the stringent system requirements. This report documents the findings of that team of specialists.

\section{THE PROPOSED $1050 \mathrm{~K}$ DESIGN}

A cutaway drawing of the Stirling Space Engine (SSE) $1050 \mathrm{~K}$ superalloy design is shown in figure 1. The engine receives energy through an assembly of sodium ( $\mathrm{Na}$ ) heat pipes from a nuclear heat source. A similar engine design could be coupled with a solar receiver and concentrator, if desired. The heat from the condensing $\mathrm{Na}$ passes through the heat pipe walls and heats the helium (He) working fluid. The regenerator is used to store most of the heat from the He working fluid as it passes from the hot side to the cold side. It returns 
the heat to the gas on the reverse part of the cycle. Heat is removed from the cold end heat exchanger by NaK, a sodium-potassium eutectic, flowing around the He containment tubes and out to a radiator of an undefined design. The ideal Stirling cycle consists of isothermal compression and expansion processes and two constant volume processes when the working fluid is shuttled between the hot and cold sides by the displacer. Power is produced by the motion of the power piston. The magnet assembly of the linear alternator is attached to the power piston and moves with it, producing electrical current in the copper wire windings. Hydrodynamic gas bearings are incorporated into the engine design to reduce friction losses and increase engine efficiency. A tentative selection of materials was made by the contractor for various engine components in the proposed design. These are given in figure 2 and table I.

\section{CONSTRAINTS ON MATERIALS SELECTION}

The $1050 \mathrm{~K}$ superalloy design for the SSE has several requirements which impose considerable constraint on the selection of construction materials (ref. 3).

The temperature of the hot end heat exchanger wall is set at $1050 \mathrm{~K}$, which establishes the maximum engine temperature. The highest temperatures of the He gas will be close to this value. Since the engine is expected to be well insulated, all structures exposed to the hot He must be considered to be at approximately $1050 \mathrm{~K}$.

The low temperature of the engine is set by the temperature of the wall of the cold end heat exchanger, $525 \mathrm{~K}$. Structures between the gas in the hot end heat exchanger, or hot section of the displacer piston, and the NaK-cooled area are assumed to have a linear temperature gradient. All other structures are assumed to be $550 \mathrm{~K}$ due to heating caused by normal power losses.

The engine is to function unattended for $60000 \mathrm{hr}$ at design power. As a result, assured longtime materials performance is extremely critical. Since this engine is proposed for use in man-rated space vehicles, it must meet the man-rated pressure vessel design requirement. This specifies that such pressure vessels must be designed for failure in no less than four times the desired system life (ref. 4), which in this case is $240000 \mathrm{hr}$.

The final constraint considered was the need to minimize magnetic losses. High efficiency in the conversion of the kinetic motion to electrical energy is essential. A major source of loss is the interaction of the surrounding structures with the magnetic field. Ideally all magnet support structures and the structures in the immediate vicinity of the magnets should be nonmagnetic and have a low electrical conductivity.

\section{ASSESSMENT}

For convenience of the materials assessment, the SSE design was divided into six "segments." These were: pressure vessel, heat exchangers, displacer assembly, power assembly, alternator assembly and dynamic balance assembly. Each segment was analyzed as described below. 
The engine components that are part of the hot end pressure vesse 1 and manifold are indicated in figure 3. The remainder of the pressure vessel can be seen in figure 2. The pressure vessel contains the He working fluid at a pressure of $18.5 \mathrm{MPa}$ with an operating frequency of $90 \mathrm{~Hz}$ and a pressure amplitude of $2.0 \mathrm{MPa}$. It must have an estimated life to failure of at least four times the expected operational life. The temperature of the vessel varies from $1050 \mathrm{~K}$ at the hot end to $525 \mathrm{~K}$ at the cold end heat exchanger and about $550 \mathrm{~K}$ at the other cold end structures. The pressure vessel also will have penetrations for heat pipes and electrical power feedthroughs. The construction materials proposed by the contractor, Sunpower, Inc., for the three regions of the structure are: Incone $1713 \mathrm{C}$ for the hot end; a high strength steel such as type 316 stainless steel for the cold region; and Inconel 625 for transition between the hot and cold ends. The remainder of this section provides the assessment team's evaluation of these proposed materials with respect to property requirements and fabricability.

The pressure vessel must meet the following requirements: (1) it must have adequate creep rupture strength, 1 percent creep strength and fatigue resistance; (2) it must be leak-tight; and (3) the materials must be fabricated and joined easily. The 1 percent creep strength is needed in those areas where dimensional stability and maintenance of low leakage seal paths are critical to engine efficiency. Creep rupture and fatigue resistance, while they are normally important, become especially critical due to man-rated safety requirements. The pressure vessel must be leak-tight to conserve the He working fluid. In addition, there are two locations in the pressure vessel where successful joining by welding or high temperature brazing techniques is critical.

Because of the operation in the vacuum of space for $60000 \mathrm{hr}$, an estimate of the extent of material loss due to vaporization was made and is illustrated in figure 4. Vaporization loss appears to be acceptably low for the types of material considered for the pressure vessel.

The creep rupture lives of the proposed materials are presented in figure 5 at a stress level of $125 \mathrm{MPa}$ (refs. 5 to 12). The original pressure vessel was designed to operate with an internal stress of $125 \mathrm{MPa}$, which represented the contractor's original safety factor ( 90 percent of the stress required to produce 1 percent creep in $85000 \mathrm{hr}$ ) in Inconel $713 \mathrm{C}$ at $1050 \mathrm{~K}$ (ref. 3). Although this operating stress could be reduced by increasing the vessel wall thickness, the $125 \mathrm{MPa}$ stress was chosen as the basis for this materials comparison. The time lines for the $60000 \mathrm{hr}$ operating design life and the $240000 \mathrm{hr}$ pressure vessel safety requirement have al so been superimposed on figure 5 . It can be seen that Inconel $713 \mathrm{C}$ will meet the safety requirement at $1050 \mathrm{~K}$. However, a weight penalty tradeoff would have to be made for either Inconel 713LC or Inconel 625 to meet this safety requirement at $1050 \mathrm{~K}$, because greater wall thickness would be necessary to obtain a $240000 \mathrm{hr}$ rupture life. With the present pressure vessel design, the hot end temperature would have to be at least $50 \mathrm{~K}$ lower for Inconel 713LC (at least $100 \mathrm{~K}$ lower for Inconel 625) to meet the safety requirement as far as creep rupture life is concerned. Likewise, type 316 stainless steel would be restricted to $850 \mathrm{~K}$ or lower in order to satisfy this pressure vessel safety requirement. 
The 1 percent creep strength requirement would apply to the high temperature and transition sections, where dimensional stability is important. Data for the time to 1 percent creep strain are compared in figure 6 (refs. 5 and 8) for Inconel $713 \mathrm{C}$ and Inconel 625. Similar data for Inconel 713LC were not available. With the limited data available, Inconel $713 \mathrm{C}$ appears to meet the $240000 \mathrm{hr}$ safety requirement at $1050 \mathrm{~K}$. The Inconel 625 data were also 1 imited; it appears to meet these requirements only below about $920 \mathrm{~K}$ in this pressure vessel design.

Caution must be exercised when using the creep data avallable in the literature. First of all, differences in alloy composition, heat treatment and grain size can lead to significant differences in creep properties. Secondly, these longtime creep properties were obtained in all cases from extrapolations of life data and 1 percent creep strain data which were at least an order of magnitude lower than the pressure vessel safety requirement of $240000 \mathrm{hr}$. For example, with Inconel $713 \mathrm{C}$ (ref. 6), the longest rupture life and the longest time to 1 percent creep strain reported in the temperature range of interest were 20000 and $2500 \mathrm{hr}$, respectively. The longest life and longest time to 1 percent creep strain reported for Inconel 625 (ref. 8) were about 50000 and $10000 \mathrm{hr}$, respectively.

The pressure vessel materials recommended by the contractor appear to have adequate fatigue resistance (table II) under their proposed use conditions, even at an $R$ value (ratio of maximum to minimum stress) of (-)l (fully reversible stress), with the exception of coarse grained Inconel 713C. In the coarse grained ( 0.48 to $0.64 \mathrm{~cm}$ average diameter) condition (ref. 5), the extrapolated Inconel $713 \mathrm{C}$ data barely meets the required $125 \mathrm{MPa} 1$ imit at $60000 \mathrm{hr}$, and fails to meet it at the $240000 \mathrm{hr}$ requirement. However, in the fine grained $(0.16 \mathrm{~cm}$ average diameter) condition (ref. 5), the extrapolated Incone $1713 \mathrm{C}$ data does appear to meet the requirements. As indicated in table II, both Inconel 625 and type 316 stainless steel possess adequate fatigue resistance.

The material choice for the cold region of the pressure vessel was a high strength stainless steel. Because of the proximity of the pressure vessel to the alternator assembly, a nonmagnetic material is required. Type 316 stainless steel is a fully acceptable selection (ref. 12). It has a fatigue endurance limit well above the $125 \mathrm{MPa}$ level (table II). It also has good creep rupture life (fig. 5).

This critical review of the properties of superalloys and high strength steels confirmed the pressure vessel material choices presented by the contractor. These materials have what is considered to be the best combination of properties (strength, ductility and ease of fabrication) of the materials presently available. Because of its superior creep resistance, adequate fatigue resistance and nonmagnetic properties, Inconel $713 \mathrm{C}$ was the assessment team's choice for the high temperature region of the pressure vessel. Type 316 stainless steel was the choice for the cold region (below about $800 \mathrm{~K}$ ) because it had adequate creep rupture properties in this temperature range and excellent fatigue properties at room temperature. Inconel 625 was the assessment team's choice for the transition region in the pressure vessel because of its exceptional fatigue resistance below $1033 \mathrm{~K}$ and because it had adequate creep resistance below $920 \mathrm{~K}$. Inconel 625 is also readily available (ref. 8) and thus was preferred over Inconel $713 \mathrm{LC}$. 
The assembled pressure vessel must be leak-tight, and thus the candidate materials must be fabricated easily and joined successfully. First, a high quality Inconel $713 \mathrm{C}$ casting must be produced in this complex geometry. Second, the Inconel $713 \mathrm{C}$ casting must be joined to the wrought Inconel 625 transition section and Inconel inserts used for integration of the heat pipes into the structure. These joints are critical and must be leak-tight and have the required mechanical properties. The difficulty of welding these alloys to each other rules out conventional fusion welding techniques; however, friction welding is a viable possibility and has been successfully utilized in the past in similar cases (refs. 13 to 14). Brazing is a possible alternative; however, there is some concern for forming low melting point phases in the joint area which may degrade properties (personal communication from M. Cieslak, Sandia National Laboratory).

Therefore, the assessment team recommends that Inconel $713 \mathrm{C}$ be joined to Inconel 625 by friction welding, with high temperature brazing as a backup joining method. The team further suggests that friction welding tests be performed with the correct geometries to establish the proper welding parameters for sound welds. It is also recommended that the location of the main circumferential Inconel $713 \mathrm{C} /$ Inconel 625 joint (fig. 3) be positioned in the cooler section of the transition region to help facilitate the long-term stability of the joint. Conventional welding of Inconel 625 to type 316 stainless steel should not pose any serious problem if appropriate filler metals are used to accommodate the difference in thermal expansion between the two dissimilar metals. It is imperative that the properties and long-term stability of all welded and brazed structures be determined on joints of the type considered for this structure and in an environment simulating their projected use.

Considering the above factors and the fact that materials behavior is sensitive to small variations in chemistry, especially trace element concentrations, it is strongly recommended that common heats of materials be obtained for use in all phases of development of this system. This would include all necessary materials development work through building the ground test engine and possibly a flight test engine. This would ensure uniformity of materials properties throughout all phases of the program and could lead to a set of specifications for materials to be used in similar engines.

Electrical power feedthroughs must be incorporated into the wall of the pressure vessel. Potting compounds would have both strength and stability problems. Ceramic insulation or a graded ceramic seal, welded in place, could offer the best solution.

Although some property data are extrapolated by several orders of magnitude, the choices presented by the contractor are viable ones, with the additional conditions indicated above.

\section{Heat Exchangers}

The location of the heat exchangers within the engine is indicated in figure 7. There are 40 heat pipe heat exchanger assemblies located circumferentially around the displacer assembly. Each assembly is an integral part of the pressure vessel and contains the hot end heat pipe condenser heat exchanger section, a regenerator element and a cold end heat exchanger section, shown from right to left in the model of a heat exchanger assembly shown in figure 8 . Figure 9 shows a model of the assembled heat pipe heat exchanger assembly. 
The function of the heat pipe is to transfer heat from the nuclear reactor to the engine as illustrated schematically in figure 10. Sodium inside the heat pipes is vaporized by the reactor heat in the evaporator end of the pipe. The $\mathrm{Na}$ vapor is condensed in the engine, where it gives up its heat of vaporization to the heat pipe walls. The heat is then transferred across the walls and is picked up by the He gas flowing next to the heat pipes. A more detailed sketch of the hot end heat exchanger is shown in figure 11 . For about half of its working cycle, the heated He flows into the regenerator, giving up some of its heat energy and moves on into the cold end heat exchanger, where it is cooled further. The reverse happens during the remainder of the cycle when the He returns.

The heat pipe materials must meet several requirements. Any material in contact with the $\mathrm{Na}$ must be resistant to $\mathrm{Na}$ corrosion. A means of providing wicking action must be available with the corrosion resistant alloy for the return of liquid $\mathrm{Na}$ to the evaporator end of the heat pipe. The material must have the strength to withstand the difference between the low internal pressure of the $\mathrm{Na}$ vapor and the pressure of the He gas on the outside. In addition, the material must be easily joined to the pressure vessel wall to provide a leak-tight seal, because the close out tube (fig. 11) also functions as part of the pressure vessel.

The most severe strength application within the power module assembly is the close out tube. The proposed design sufficiently reduces the stress level in the close out tube wall to permit the use of Inconel 625 (fig. 11). As indicated previously in figure 4, Inconel 625 appears to have acceptably low estimated vaporization loss over the system operation life. From a $\mathrm{Na}$ corrosion standpoint, however, Inconel 625 is not recommended due to the very long operational life required. It has a high $\mathrm{Ni}$ content (6I percent $\mathrm{Ni}$ ). High $\mathrm{Ni}$ content alloys have been demonstrated to have less corrosion resistance than lower $\mathrm{Ni}$ content alloys (refs. 15 and 16). Therefore, a conservative approach should be taken and high $\mathrm{Ni}$ content alloys avoided. A low $\mathrm{Ni}$ content alloy such as Incoloy 800 HT (32.5 percent $\mathrm{Ni}$ ) would be acceptable from a corrosion standpoint as long as the oxygen content was controlled to a level below 1 $\mathrm{ppm}$. To ensure long time corrosion resistance, this low level of oxygen must be maintained in the $\mathrm{Na}$ over the entire system life. To accomplish this, a method of oxygen removal, such as the use of a getter material, must be incorporated into the heat pipe design.

Although Incoloy $800 \mathrm{HT}$ has the better corrosion resistance, it does not have the required strength, its strength being comparable to that of type 316 stainless steel (fig. 5). However, it is feasible that a heat pipe structure can be fabricated having an inner lining of Incoloy 800 HT and an outer layer of Inconel 625, giving the structure the necessary strength and corrosion resistance. But, such a structure must have high thermal conduction across the joint. This would require a joining method which produces intimate contact, such as coextrusion, diffusion welding, or brazing. Coextrusion is the preferred method because of the ease of fabrication and the uncertainties of the effects of braze material in $\mathrm{Na}$ systems.

Metal matrix composites also were considered. Their potential for a combination of strength and corrosion resistance makes then very attractive; however, their use is not recommended here. A preliminary development effort on these composites is in progress, but considerable development time is necessary before they can be used in an actual system. Techniques must be developed for 
their fabrication into the required shapes and sizes. A property data base must also be established. Although such composites cannot be recommended for use at this time, they have a definite potential for later systems.

The location of the regenerator is also indicated in figures 7,10 , and 11. Its function is to increase the efficiency of the Stirling cycle by recovering heat from the He as it flows from the hot end to the cold end and transferring the recovered heat back into the He on the reverse cycle. The regenerator structure consists of a porous metallic mass, typically stacked wire screens, to provide a large surface area for effective heat transfer.

Materials for this application must have excellent heat transfer capability and have a structure which maximizes the surface area exposed to the gas flow. A wire screen construction, proposed by the contractor, has been demonstrated as a very effective way to provide this. The selection of a specific material for this segment of the system is not based on mechanical properties of the material. In a superalloy system such as this, major problems due to outgassing of this material are not expected. The assessment team did not feel additional investigation in this area was warranted. The selection of stainless steel was accepted by the team as adequate.

Figures 12 and 13 show the layout and functioning of the He/NaK cold end of the heat exchanger modules and the baffles and manifolds which circle the engine pressure vessel and remove waste heat from the engine. The cooling fluid is pumped from the engine through the exit manifold by way of piping to a radiator of an undefined design and back again to the engine through the entry manifold. NaK was proposed as the cooling fluid. OFHC (oxygen free, high conductivity) copper and $\mathrm{Ni} 270$ (high purity nickel) were proposed as possible materials for the high thermal conductivity finned sleeve on the He side of the heat exchanger. Inconel 625 was proposed as the material for the high strength shell of that section, its outer tube, and the baffles, exchanger wall, manifold, and partitions.

Since the cooling fluid must be liquid at all temperatures of operation, NaK is the best selection. NaK would give the least problems during startup, operation and shutdown since it is typically liquid at 260 to $310 \mathrm{~K}$, depending on actual composition.

The finned sleeve must be a high conductivity material. From this standpoint, OFHC copper is the best choice. If problems develop with fabrication of the assembly, specifically brazing of the parts, Ni 270 should be considered the backup material. Its thermal conductivity (ref. 19) is not quite as good, but would be sufficient.

If Inconel 625 is used for the corresponding pressure vessel wall in this location in the engine, it should be the best selection for those portions of the heat rejection system which are in contact with the NaK. Inconel 625 is compatible with NaK at these temperatures (refs. 16 and 17). It is fabricated easily (ref. 9). However, another look should be taken at the construction of this section of the engine. The feasibility of casting this portion of the system as part of the Inconel $713 \mathrm{C}$ pressure vessel wall should be determined. Such a complex investment casting, if feasible, would still be corrosion resistant and would probably be less expensive to produce. 
This heat exchanger portion of the system, as proposed, has some inherent fabrication issues. Areas of concern are: (1) the assembly of the baffled plenum, (2) brazing of 40 tubes into the plenum, (3) braze joint integrity, (4) the braze alloy compatibility with NaK, (5) long term stability of the braze joints, and (6) production of the assembly by casting or brazing techniques.

\section{Displacer Assembly}

The location of the displacer structure is indicated by the shaded area in figure 14 and shown in greater detail in figure 15. The function of the displacer is to provide the reciprocating pumping action for the He gas through the heat exchangers.

The dome and radiation shield materials were proposed as Inconel 718 . A "stuffer" material made of Inconel 718 felt-metal with an Inconel 718 inner shell was proposed to reduce the amount of gas space between the dome and the pressure vessel wall. The seals, piston, cylinder wall, and bearing materials were proposed as Be. All bearing surfaces were proposed as being given a wear resistant coating of TiN. The team considered, in addition to the above, the use of aluminides, a SiC-SiC composite and $\mathrm{Si}_{3} \mathrm{~N}_{4}$ as structural materials and $\mathrm{MoS}_{2}$ as a coating.

The displacer assembly must have a low density and have a coefficient of thermal expansion close to that of the cylinder wall. The coating must provide nonbonding, antigalling, low coefficient of friction mating surfaces with surrounding parts.

Because of its matching coefficient of expansion, Inconel 718 was considered the best choice for the displacer dome and radiation shields. Because of its low density and reasonable coefficient of expansion, and extensive database, Be was the favored selection for the seals, piston, cylinder wall and bearings, although the SiC-SiC composite (ref. 20) should be considered an attractive candidate. The lack of extensive characterization and its estimated 10 percent open porosity are its only weak points. The porosity could be corrected, if needed, by a surface impregnation but would require some development effort. As a surface coating, TiN appears to be the most suitable material because of its high hardness and high temperature stability. However, the adherence and tribological properties of TiN coatings must be determined for these specific operating conditions. Although $\mathrm{MOS}_{2}$ effectively reduces friction, does not spall from the surface and is easily applied, it is not recommended because of the concern of compatibility of the other system materials with sulfur.

There are some other issues and concerns which must be addressed. Although He gas is nominally the environment for the system, oxygen will be present due to outgassing from all surfaces, especially from insulation, in the space environment. Be oxidizes readily. This could pose a serious structural and operational problem. Low pressure oxidation testing is therefore required. Also, a sound Be/Inconel 718 joint must be achieved in the displacer. The procedure for this must be developed. The fabrication techniques and joint soundness must be established. 
The power assembly is indicated in figure 16. The function of the power piston is to provide the reciprocating motion for the production of power in the alternator assembly. The piston is supported by gas bearings and must be free to move axially over the length of the stroke between the inner gas spring housing and the outer cylinder. It must be stiff and maintain its dimensional stability to maintain the proper seals and bearings.

The contractor proposed Be for the piston and cylinder wall, a high strength titanium alloy for the inner gas spring housing and TiN as the bearing surface coating. The team also considered aluminides, a SiC-SiC composite, and $\mathrm{Si}_{3} \mathrm{~N}_{4}$ as the piston and cylinder material.

Be, with its high elastic modulus and low coefficient of thermal expansion (ref. 21), is considered to be the best choice for the piston. The cylinder wall is an extension of the displacer cylinder wall and, therefore, is Be. The inner gas spring housing is part of the balance piston assembly. Titanium alloys, although they have somewhat lower thermal coefficients of expansion, have higher density. Unless there is an overriding system justification, the lower resulting engine weight would justify the selection of Be; however, SiCSiC composite is an attractive alternative. TiN appears to be the best choice as a bearing surface coating.

\section{Alternator Assembly}

The alternator assembly is indicated by the shaded area of figure 17. The alternator transforms the kinetic energy of the power piston into electrical energy by the interaction of the electrical coil with the magnetic field as the magnets move with the power piston plunger. The temperature of the assembly must be held below the temperature at which the magnets degrade. Auxiliary cooling will be used if necessary. To maximize system efficiency, the surrounding structural members should be nonmagnetic and have a low electrical conductivity to minimize interaction with the magnetic field. All insulation and adhesives must be stable under the use conditions.

The contractor proposed copper wiring, Hyperco 50 steel stator laminations, $\mathrm{Sm}_{2} \mathrm{CO}_{17}$ magnets, high strength titanium alloy supporting members and a graphite reinforced polyimide matrix for the plunger. In addition to these, the team evaluated the application of SiC-SiC composites and aluminides.

Copper is the best known, most widely used electrical conductor and is expected to perform adequately in the proposed environment. The same is expected of Hyperco 50. The $\mathrm{Sm}_{2} \mathrm{CO}_{17}$ magnet material is characteristic of the class of known high temperature permanent magnets and appears to be a suitable choice. However, the life of $\mathrm{Sm}_{2} \mathrm{CO}_{17}$ under the conditions of cyclic loading and a temperature of $525 \mathrm{~K}$ for the $60000 \mathrm{hr}$ engine life requirement is a question and testing is required.

Materials considered for the structural support members were graphite fiber reinforced polyimide matrix composites. The materials considered for the alternator assembly and other segments of the system are listed, along with their room temperature electrical resistivities and magnetic permeabilities, in 
table III. The electrical conductivity of titanium alloys would result in significant magnetic interaction when used in this proximity. The aluminides generally have relatively high density and poor fabricability; those with desirable high modulus have poor ductility. The polyimide matrix composites are predicted to have long life in He at the expected temperatures (ref. 27). They have low density (ref. 28), a tailorable coefficient of thermal expansion (ref. 29), and electrical resistivity of the order of $500 \mu \Omega-\mathrm{cm}$ (ref. 26 ). Further, they are dimensionally stable (ref. 30), strong and stiff (refs. 28 and 32). However, the interaction of the graphite fibers in the composite with the magnetic fields is unknown. The SiC-SiC composites are believed to have very low interaction with magnetic fields, are chemically and physically stable, strong and stiff and they have low density (ref. 16). The SiC-SiC composite is the prime recommendation of the assessment team as the structural support material, with graphite reinforced polyimide composite as a backup.

Common electrical insulation materials are generally unstable under the projected use conditions. It is recommended that alumina be used whenever possible. For electrical feedthroughs, alumina should be considered if graded ceramic seals are not feasible.

Adhesives are generally unstable under the projected use conditions. Techniques of mechanical positioning and fastening should be investigated.

\section{Dynamic Balance Assembly}

The location of the dynamic balance piston and the cylinder are indicated in figure 18 and shown in greater detail in figure 19. The balance piston provides an opposing vibration of sufficient magnitude to cancel the vibrations caused by all the other moving parts of the engine. This segment is in the lower temperature $(550 \mathrm{~K})$ end of the engine. The main requirements are a high balance mass and a close tolerance bearing/seal.

The materials proposed by the contractor were a depleted uranium for the balance mass, a high strength titanium alloy for the cylinder structure and TiN as a hard protective coating on the bearing surfaces. The team also looked at tungsten for use as the balance mass.

Although tungsten has a density suitable for this application $\left(19.3 \mathrm{~g} / \mathrm{cm}^{3}\right)$ (ref. 23), uranium has an equally attractive density $\left(19.1 \mathrm{~g} / \mathrm{cm}^{3}\right)$ (ref. 23 ). On the basis of matching the coefficients of thermal expansion with that of a titanium alloy, uranium is the better selection. Tungsten should be considered an alternate choice. The commonly available titanium alloys, such as Ti-6Al-4V, are relatively lightweight and stiff, so they would be good cylinder material selections. As the bearing surface coating, TiN needs additional adherence and tribological testing.

\section{RECOMMENDATIONS}

\section{System Cleanliness}

Utmost cleanliness of engine parts must be maintained because of the presence of alkali metals in the system ( $\mathrm{Na}$ in the heat pipes, NaK in the heat 
rejection system, and $\mathrm{Li}$ in the nuclear reactor) and the potential for transport of contaminating gases $\mathrm{CO}_{2}, \mathrm{H}_{2} \mathrm{O}, \mathrm{CO}, \mathrm{CO}_{2}, \mathrm{~N}_{2}$, etc.) through the He gas over the lifetime of the system. In addition, these contaminants can accummulate in the $\mathrm{Na}$ and $\mathrm{NaK}$ causing further corrosion or plugging problems. Therefore, incorporation of $\mathrm{NaK}$ and $\mathrm{Na}$ purification techniques in the design of those parts of the system is strenuously urged to prevent corrosive attack. This also means that some kind of clean room operation and procedures must be established, along with surface cleaning and vacuum bakeout of all engine parts prior to assembly and maintenance of this cleanliness during assembly.

\section{Materials Selection}

It is recommended that common heats or batches of materials be obtained for all testing, development and system fabrication steps in the overall system R\&D and initial engine tests because of the variability in composition and properties of materials from one heat or treatment batch to another. Experience gained from these heats can result in materials specifications for additional systems of this type.

The materials choices of the contractor for the various parts of the $1050 \mathrm{~K}$ superalloy design of the Space Stirling Engine are listed in table I. The recommendations made by the materials assessment team are listed in table IV. The following describes in detail the choices which differ, the reasons for these differences, and recommended development work.

Pressure vessel. - The demanding safety requirements of the engine require the Incone $1713 \mathrm{C}$ in the hot end of the engine to be fine grained $10.16 \mathrm{~cm}$ average grain diameter). Creep rupture and 1 percent creep strain properties and the safety requirements restrict the use of the other alloys of choice, Inconel 625 and type 316 stainless steel. Inconel 625 should be used in this design in the transition parts exposed to moderate temperatures below $900 \mathrm{~K}$, although it is recommended that the Inconel $713 \mathrm{C}$ /Inconel 625 joint be located in the cooler portion of the transition region, as far away from the hot end as possible. Type 316 stainless steel should be used in the cold end of the pressure vessel (no higher than $800 \mathrm{~K}$ ). Because of the uncertainty in the ability to produce sound joints between cast Inconel $713 \mathrm{C}$ and the wrought Inconel 625 alloys by friction welding, trial welds must be made using shapes approximating those of the design parts. Also because of this uncertainty, backup studies for brazing these parts to produce strong, sound joints must be initiated. Properties of both the welded and brazed joints must be determined. This includes the welded Inconel 625/type 316 stainless steel joint. Welds for the incorporation of graded ceramic seals must be investigated. If a satisfactory graded seal is not readily available, a development effort should be considered. Work on the backup ceramic feedthrough seal is needed also.

Heat exchangers. - Coextruded Inconel 625/Incoloy $800 \mathrm{HT}$ tubing was the assessment team's choice because this was believed to be the only way to provide both the necessary strength and corrosion resistance for the $\mathrm{Na}$ heat pipe. The coextrusion method for producing Inconel 625/Incoloy $800 \mathrm{HT}$ tubing must be demonstrated and heat pipes of this material must be fabricated. Brazing seems to be the only practical method of joining the heat pipes to the pressure vessel wall. Once the heat pipes are fabricated, the effect of any further exposure to heat, such as brazing heat treatments, on their operational characteristics must be determined. Properties of the braze joints must be 
demonstrated and the method proven to be feasible and effective. Because of the very attractive properties of metal matrix composites, it al so is recommended that development of metal matrix composite heat pipes be pursued in anticipation of their use in future systems. The prime choice of the assessment team for the finned structure in the cold end heat exchanger was OFHC copper because of its better thermal conductivity. Brazing tests must also be performed to demonstrate the ability to produce full brazing and good thermal transfer across the Inconel 625/Cu joints. If problems develop with brazing $\mathrm{Cu}, \mathrm{Ni} 270$ would be the backup material.

The fabrication of the cold end heat exchanger is very complex and the feasibility of producing it by brazing must be demonstrated. Long term corrosion tests must be performed to demonstrate the compatibility of these brazed joints with NaK and to determine that there is no detrimental effect anywhere in the heat exchanger caused by transfer of components of the braze alloy. The team also recommended a study of the feasibility for producing this cold end heat exchanger by casting it out of Inconel 713C. Very complex parts can be investment cast. If the use of an Inconel 625 transition section can be eliminated, it would simplify the problems somewhat; however, a dependable method of joining Inconel $713 \mathrm{C}$ to type 316 stainless steel would have to be proven, since no joining data could be found on this material combination.

Displacer assembly. - Critical to the selection of Be is its structural integrity throughout the life of the engine. Be is readily oxidized. Oxygen can be introduced into the system though the degassing of materials during system operation. The He gas will carry the oxygen through the system. The extent of the effects of this oxygen on the Be must therefore for determined. Be also must be brazed to Inconel 718. The integrity and properties of such a joint must be established. The adherence and tribological properties of the TiN coating must be proven. The team recommended the SiC-SiC composite as a backup to Be. Because this material is new and has not had extensive use, much testing must be done to definitely establish its potential for this application. A method of joining it to the Inconel 718 must be established. Demonstration testing must be performed.

Power assembly. - SiC-SiC composite was recommended as a backup to Be here, as in the displacer assembly. The use of TiN coatings in this part also requires the demonstration of its adherence to the substrate material and of its tribological properties.

Alternator assembly. - SiC-SiC composite was the choice of the assessment team for the structural members of the alternator assembly, primarily because of its lack of interaction with the magnetic field. Methods of joining it to the other materials must be determined. The graphite reinforced polyimide, as a backup choice, must be tested to determine the extent of interaction with magnetic fields because of the conductivity of the graphite fibers.

Although $\mathrm{Sm}_{2} \mathrm{Co} 17$ appears to be the best choice for magnets, it must be tested to determine the extent of potential effects of cyclic loading at $525 \mathrm{~K}$ on its magnetic properties.

The use of adhesives was not recommended. Mechanical positioning and fastening methods must be investigated. 
Dynamic balance assembly. - Although depleted uranium remained the recommended high density material in this section, the team recommended the consideration of tungsten as an alternate, because tungsten is readily available and has a comparably high density.

The adherence and tribological properties of TiN, in its application here, also need to be demonstrated.

\section{CONCLUDING REMARKS}

The materials assessment team, which was assembled to evaluate the proposed materials selections by the contractor and to make alternate materials choices where they thought feasible, has concluded its assessment work. The team concurred in general with the selections proposed by the contractor. In a few instances in this report, different materials are proposed or alternates suggested.

The team also concluded that much testing and development work remains to be done in the near future and has made recommendations in that area. Additional information is needed to give greater confidence that the selections will meet the requirements imposed on the engine.

Among the needs are:

1. Friction weld test of Inconel $713 \mathrm{C} /$ Inconel 625 ;

2. Braze tests for all potential braze joint combinations;

3. Trial runs for producing Inconel 625/Incoloy $800 \mathrm{HT}$ coextruded tubing and demonstration of fabricating this tubing;

4. Evaluation of graded ceramic seals and ceramic feedthroughs;

5. Determine feasibility of casting the entire hot end of the pressure vessel of Inconel $713 \mathrm{C}$, from $1050 \mathrm{~K}$ to the cold end of the alkali metal heat exchanger section;

6. Long-term compatibility testing of the heat exchanger section;

7. Beryllium oxidation testing;

8. Adherence and tribological testing of TiN coatings;

9. Fabrication and testing of SiC-SiC composite components;

10. Testing of $\mathrm{Sm}_{2} \mathrm{Co} 17$ magnets under cyclic loading at $525 \mathrm{~K}$.

It must be emphasized that these findings apply only to the superalloy $1050 \mathrm{~K}$ Stirling Space Engine design. All segments of the engine would have to be reevaluated for any other class of materials or temperature of operation.

\section{ACKNOWLEDGEMENTS}

The team thanks all those who where helpful in providing information for this evaluation: Mr. Barry Penswick, formerly of Sunpower, Inc.; Dr. Michael Cieslak of Sandia National Laboratory; and Mr. John Reagan and Mr. Harold Sliney of NASA Lewis Research Center for providing additional technical input at the request of the team: also, Mr. Donald Alger of Sverdrup Technology, Inc.; and Mr. Larry Thieme and Mr. William Tomazic of NASA Lewis Research Center for providing information on the construction and functioning of the Stirling engine and for reviewing the draft of this report with respect to accuracy of the system construction and functioning. With the input from these people, a broader scope was possible in this assessment of materials capability and applications. 


\section{REFERENCES}

1. Slaby, J.G.: Overview of NASA Lewis Research Center Free Piston Stirling Engine Activites. NASA TM-83649, DOE/NASA/1005-2, 1984.

2. Brown, A.T.: Space Power Demonstrator Engine. (MTI-87TR36, Mechanical Technology Inc.; NASA Contract NAS3-23883) NASA CR-179555, 1987.

3. Penswick, L.B.: $1050^{\circ} \mathrm{K}$ Stirling Space Engine Design. NASA CR-182149, 1988.

4. Ecord, G.M.: Space Station Fracture Control Plan. JSC-19649, NASA Johnson Space Center, Apr. 1984.

5. Manson, S.S.: Incone1 713C. Aerospace Structural Metals Handbook, Code 4119, Sept. 1976, Metals and Ceramics Information Center, 1986.

6. Engineering Properties of Alloy 713C. The International Nickel Company Inc., 1980.

7. Manson, S.S.: Nonferrous Alloys - 713LC. Aerospace Structural Metals Handbook, Code 4108, Dec. 1976, Metals and Ceramics Information Center, 1986.

8. Manson, S.S.: Inconel Alloy 625. Aerospace Structural Metals Handbook, Code 4117, June 1976, Metals and Ceramics Information Center, 1986.

9. Inconel Alloy 625. The International Nickel Company Inc., 1976.

10. Manson, S.S.: Incoloy, Alloy 800H. Aerospace Structural Metals Handbook, December 1979, Code 1615, Metals and Ceramics Information Center, 1986.

11. Incoloy 800HT. The International Nickel Company Inc., 1985.

12. Kattus, J.R.: Ferrous Alloys - Type 316,317. Aerospace Structural Metals Handbook, Code 1307, Mar. 1974, Metals and Ceramics Information Center, 1986.

13. Friction Welding. Metals Handbook, Ninth Edition, Vol. 6, ASM, Metals Park, OH, 1983, pp. 719-728.

14. High Strength Turbine Blade Dovetails. Air Force Manufacturing Methods, Contract F33615-72-C-1276, Sept. 24, 1974.

15. Stang, J.H., et al.: Compatibility of Liquid and Vapor Alkali Metals with Construction Materials. DMIC Report No. 227, Apr. 15, 1966.

(Avail. NTIS, AD-487718).

16. Collins, C.G.; Moteff, J.; and Chandler, B.A.: Evaluation of the Potential of Selected Alloys for Use as a Fuel Cladding Material in an LMFBR. General Electric Co. Report No. GEMP-573-REV, June 1969. 
17. Soenen, M.: Compatibility of Different Brazing Alloys During Long Time Exposure in Sodium Loop. Alkali Metal Coolants, International Atomic Energy Agency, Vienna, 1967, pp. 391-414.

18. Hosking, F.M.: Sodium Compatibility of Nickel Base Brazing Alloys for Refractory Metal/304L Stainless Steel Joints. SAND-83-0411, May 1983.

19. Huntington Alloys Handbook. International Nickel Company Inc., 1970.

20. Lamicq, P.J., et al.: SiC/SiC Composite Ceramics. Am. Ceram. Soc. Bull., vol. 65, no. 2, Feb. 1986, pp. 336-338.

21. Lyman, T., ed.: Metals Handbook, 8th Edition, Vol. 1-Properties and Selection of Metals. American Society for Metals, Metals Park, OH, 1967.

22. Aerospace Structural Metals Handbook. Mechanical Properties Data Center, Battelle Columbus Laboratories, 1986.

23. Brande, E.A., ed.: Smithells Metals Reference Book. Sixth Edition, Butterworths, 1983.

24. Weast, R.C., ed.: CRC Handbook of Chemistry and Physics. 58th Edition, CRC Press, 1977.

25. Campbell, I.E., ed.: High Temperature Technology. Wiley, 1956.

26 Jaworske, D.A.; Zinolabedini, R.; and Vannucci, R.D.: Mechanical and Electrical Properties of Graphite Fiber-Epoxy Composites Made From Pristine and Bromine Intercalated Fibers. J. Compos. Mater., vol. 21 , no. 6, June 1987, pp. 580-592.

27. Bowles, K.J.: Unpublished data to be presented at the 20th SAMPE Technical Conference to be held at Minneapolis, MN, Sept. 27-29, 1988.

28. Cavano, P.J.; and Winters, W.E.: Fiber Reinforced PMR Polyimide Composites. (TRW-ER-7884-F, TRW Equipment Labs; NASA Contract NAS3-20366) NASA CR-135377, 1977.

29. Campbell, M.D.; and Burleigh, D.D.: Thermophysical Properties Data on Graphite/Polyimide Composite Materials. (GDC-NAS-79-002, General Dynamics Convair Div.; NASA Contract NAS1-15103) NASA CR-159164, 1979.

30. Berman, L.D.: Reliability of Composite Zero-Expansion Structures for Use in Orbital Environment. Composite Reliability, ASTM STP-580, 1974, pp. 288-297.

31. Cushman, J.B.; and MCCleskey, S.F.: Design Allowables Test Program, Celion 3000/PMR-15 and Celion 6000/PMR-15, Graphite/Polyimide Composites. NASA CR-16584, 1982.

32. O'Brien, T.K., ed.: Long Term Behavior of Composites. ASTM STP-813, 1983. 
TABLE I. - CONTRACTOR MATERIALS SELECTIONS

\begin{tabular}{|c|c|c|}
\hline Part & Selection & Alternate \\
\hline $\begin{array}{l}\text { Pressure vessel } \\
\text { Hot end } \\
\text { Transition } \\
\text { Cold end } \\
\text { Heat exchangers } \\
\text { Heat pipe fluid } \\
\text { Heat pipe wall and wick } \\
\text { Regenerator } \\
\text { Cold end heat exchanger - } \\
\text { Fluid } \\
\text { Finned sleeve } \\
\text { Shell, manifold, } \\
\text { baffles, and walls } \\
\text { Displacer assembly } \\
\text { Dome and baffles } \\
\text { Stuffer } \\
\text { Cylinder wall, seals, and } \\
\text { bearings } \\
\text { Bearing coating } \\
\text { Power assembly } \\
\text { Piston and cylinder } \\
\text { Piston gas spring housing } \\
\text { Bearing coating } \\
\text { Alternator assembly } \\
\text { Windings } \\
\text { Laminations } \\
\text { Magnets } \\
\text { Support structure } \\
\text { Plunger } \\
\text { Dynamic balance assembly } \\
\text { Piston } \\
\text { Cylinder } \\
\text { Bearing coating } \\
\text { Pind }\end{array}$ & $\begin{array}{c}\text { Inconel } 718 \\
\text { Inconel } 718 \\
\text { Beryllium } \\
\text { TiN } \\
\text { Beryllium } \\
\text { Titanium alloy } \\
\text { TiN } \\
\text { Copper } \\
\text { Hyperco-50 } \\
\text { Sm2 Co } 17 \\
\text { Titanium alloy } \\
\text { Polymer/Gr } \\
\text { composite } \\
\text { Uranium } \\
\text { Titanium alloy } \\
\text { TiN }\end{array}$ & Type $316 \mathrm{SS}$ \\
\hline
\end{tabular}

TABLE II. - FATIGUE PROPERTIES OF POTENTIAL PRESSURE VESSEL MATERIALS

\begin{tabular}{|c|c|c|c|}
\hline Material & $\begin{array}{c}\text { Endurance } \\
\text { Jimit } \\
\left(\begin{array}{c}R=-1) \\
\mathrm{MPa}\end{array}\right.\end{array}$ & $\underset{K}{\text { Temperature, }}$ & $\begin{array}{l}\text { Refer- } \\
\text { ence }\end{array}$ \\
\hline $\begin{array}{l}\text { Inconel } 625 \\
\text { Inconel } 713 \mathrm{C} \\
\text { Coarse grain } \\
\text { Fine grain } \\
\text { Type } 316 \mathrm{SS}\end{array}$ & $\begin{array}{r}310 \text { to } 620 \\
\text { a } 152 \text { to } 234 \\
\text { b176 to } 231 \\
262 \text { to } 276\end{array}$ & $\begin{array}{l}\text { RT to } 1033 \\
\text { RT to } 1033 \\
\text { RT to } 1033 \\
\text { RT }\end{array}$ & $\begin{array}{l}6 \\
6 \\
8\end{array}$ \\
\hline
\end{tabular}

aFatigue limit at $10^{8}$ cycles

Extrapolation: $123 \mathrm{MPa}$ at $60000-\mathrm{hr} 1$ ife

$115 \mathrm{MPa}$ at 240 000-hr life.

${ }^{b}$ Fatigue limit at $10^{8}$ cycles

Extrapolation: $142 \mathrm{MPa}$ at $60000-\mathrm{hr} 1$ ife

$135 \mathrm{MPa}$ at 240 000-hr 1 ife. 
TABLE III. - ELECTRICAL RESISTIVITY AND MAGNETIC PERMEABILITY OF SELECTED MATERIALS

\begin{tabular}{|c|c|c|}
\hline Material & $\begin{array}{c}\text { Resistivity, } \\
\mu \Omega-c m\end{array}$ & Permeability \\
\hline $\begin{array}{l}\text { Inconel } 713 \mathrm{C} \\
\text { Incone1 } 625 \\
\text { Inconel } 718 \\
\text { Incoloy } 800 \mathrm{HT} \\
\mathrm{Ti-6}-4 \\
\text { Type } 316 \mathrm{SS} \\
\text { OFHC copper } \\
\mathrm{Ni} 270 \\
\text { Bery11ium } \\
\text { Tungsten } \\
\text { Uranium } \\
\text { TiN } \\
\text { SiC } \\
\text { Graphite } \\
\text { Gr/polyimide }\end{array}$ & 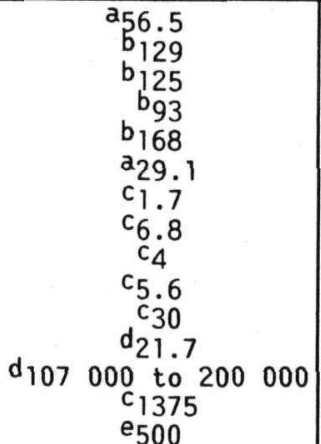 & $\begin{array}{c}a_{1} .0006 \\
a_{1} .0011 \text { to } 1.0013 \\
a_{1} .0092 \text { to } 1.0137 \\
a_{1.00005} \\
c_{1.0040 \text { to } 1.0100} c_{0.99999} \\
c_{0.99999} \\
c_{1} .00006 \\
c_{1} .00040\end{array}$ \\
\hline
\end{tabular}

aReference 23.

beference 24.

CReference 25.

dReference 26 .

e Reference 27.

TABLE IV. - TEAM MATERIALS RECOMMENDATIONS

\begin{tabular}{|c|c|c|}
\hline Part & Recommendation & Alternate \\
\hline 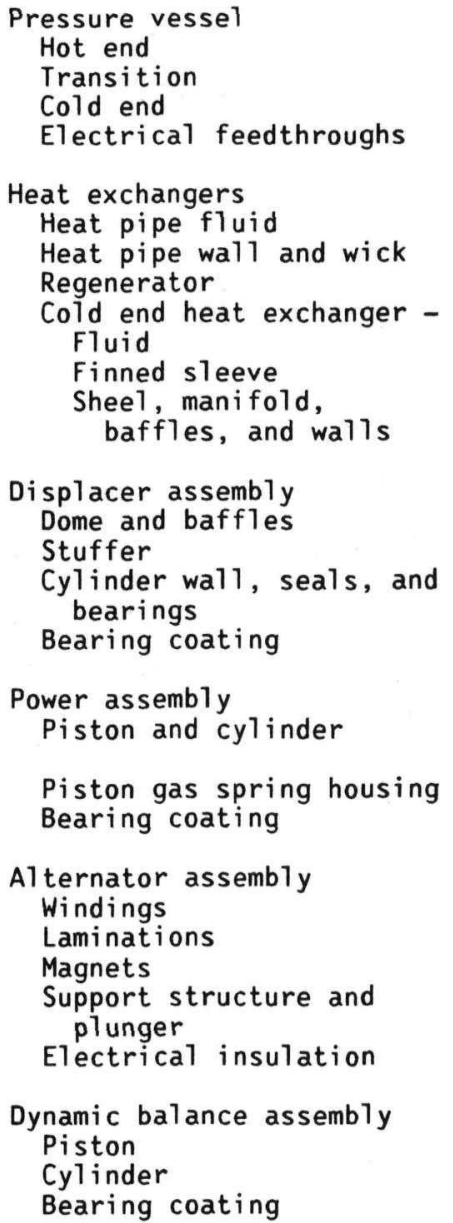 & $\begin{array}{c}\text { Inconel } 718 \\
\text { Inconel } 718 \\
\text { Beryllium } \\
\text { TiN } \\
\text { Bery11ium } \\
\text { Titanium alloy } \\
\text { TiN } \\
\text { Copper } \\
\text { Hyperco-50 } \\
\text { Sm2Co17 } \\
\text { SiC-SiC composite } \\
\text { Ceramic coating } \\
\text { Titanium alloy } \\
\text { TiN }\end{array}$ & Ceramic seal \\
\hline
\end{tabular}




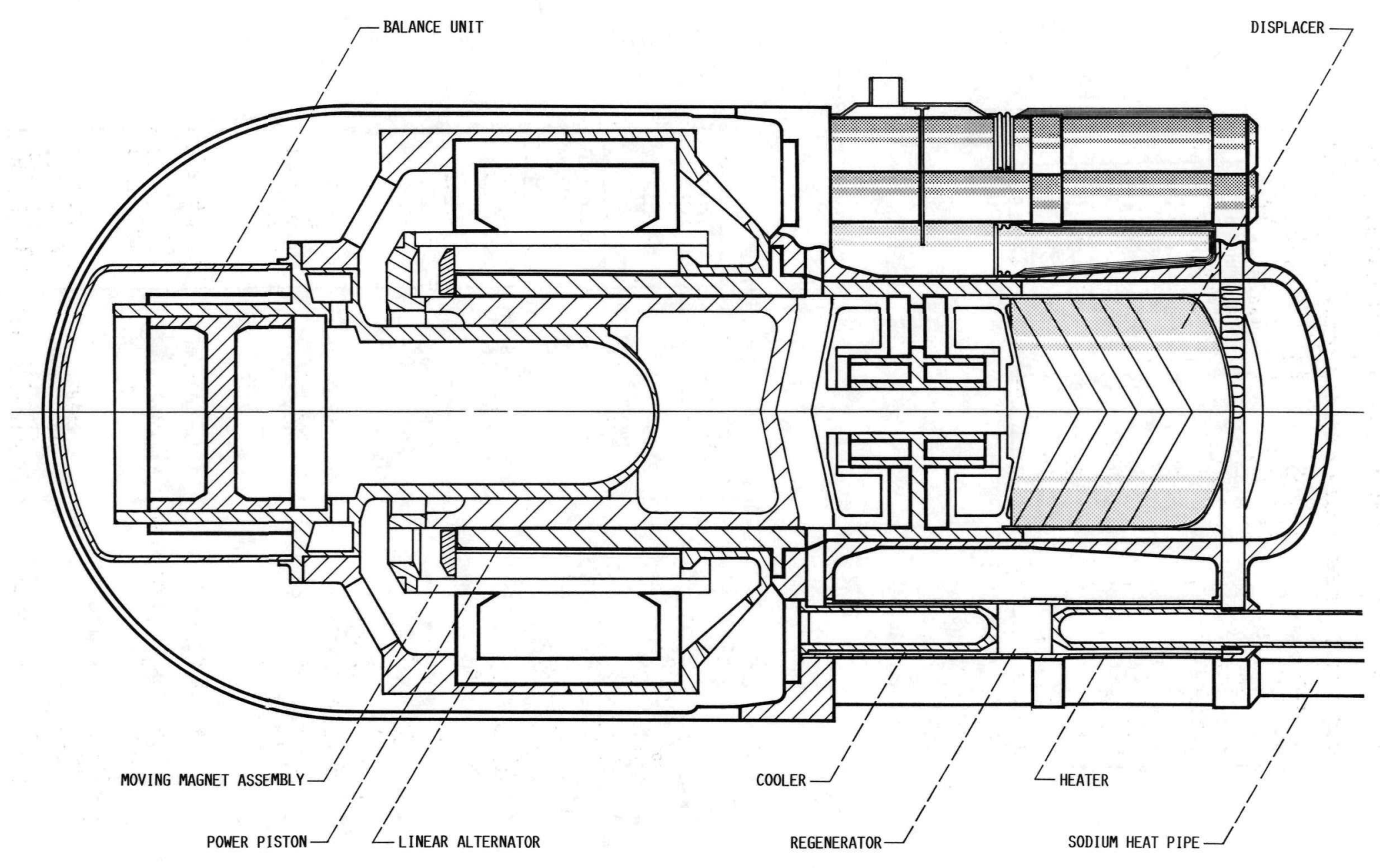

Figure 1. - Stirling SPACE ENGine $1050 \mathrm{~K}$ design (FROM ReF. 3 With Modification). 


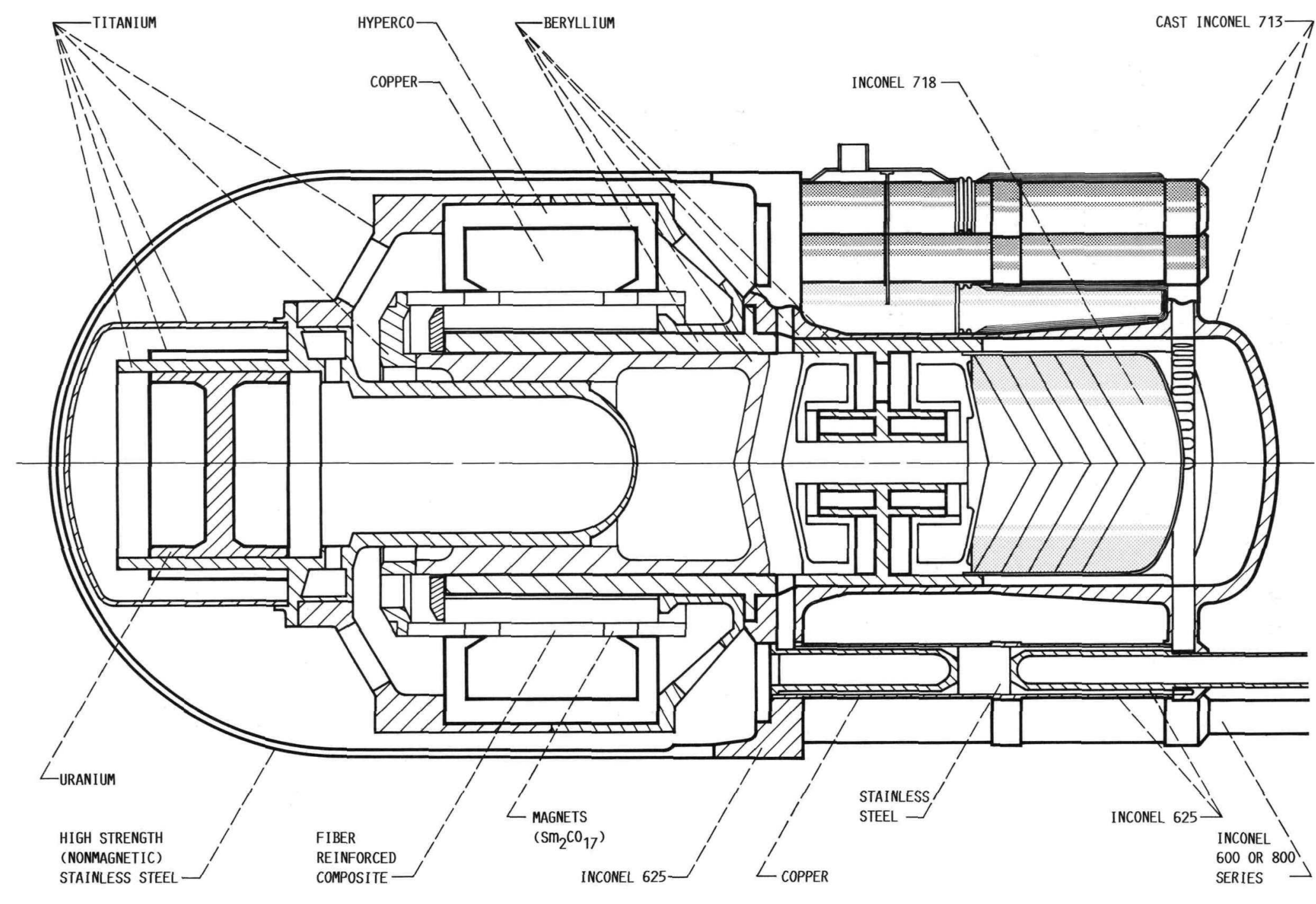

FIGURE 2. - CONTRACTOR-SELECTED MATERIALS (FROM REF. 3 WITH MODIFICATION). 

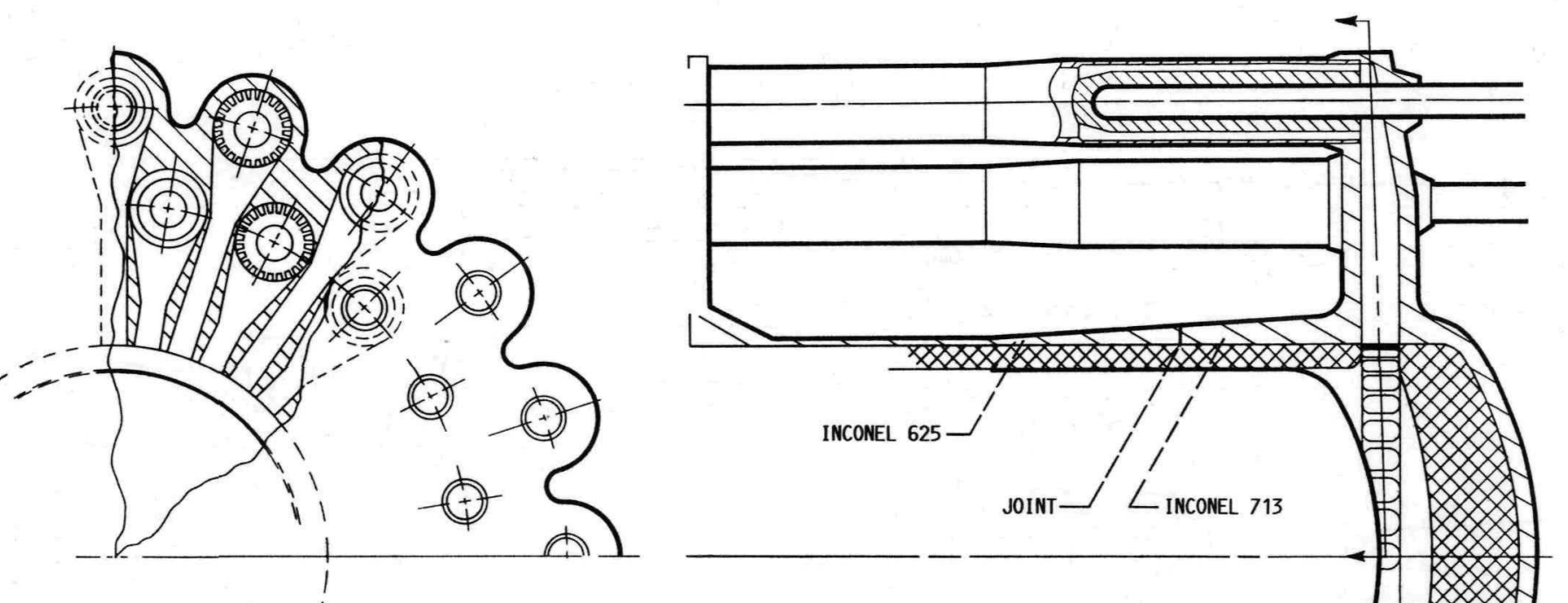

25-
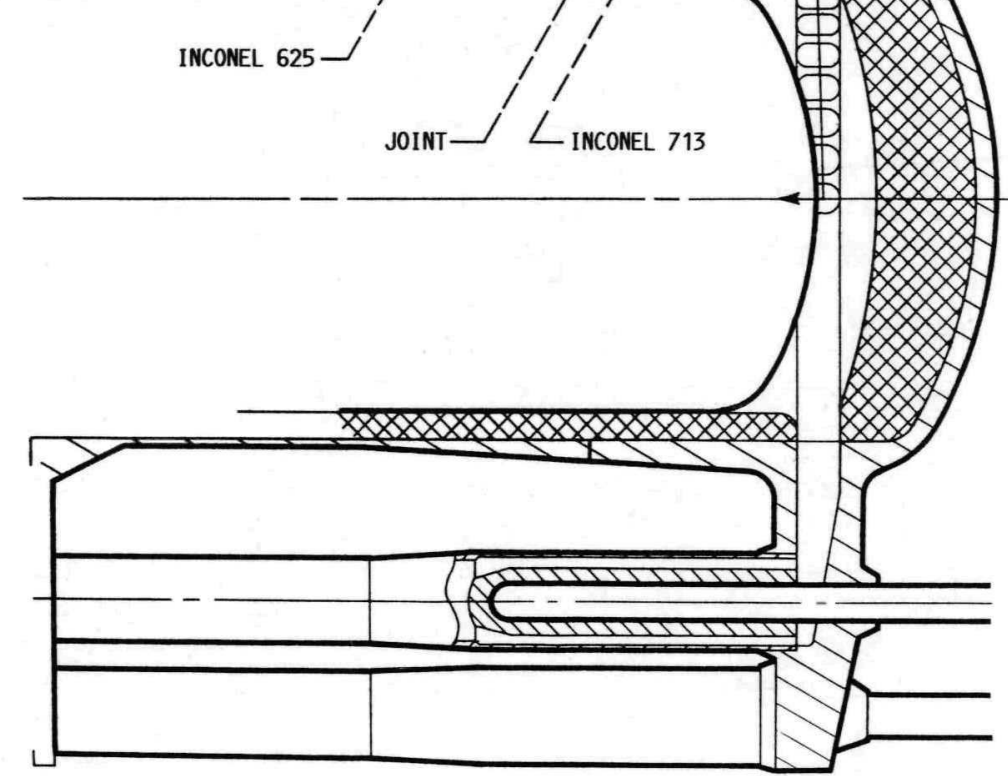

FIGURE 3. - HOT END ASSEMBLY (FROM REF. 3). 


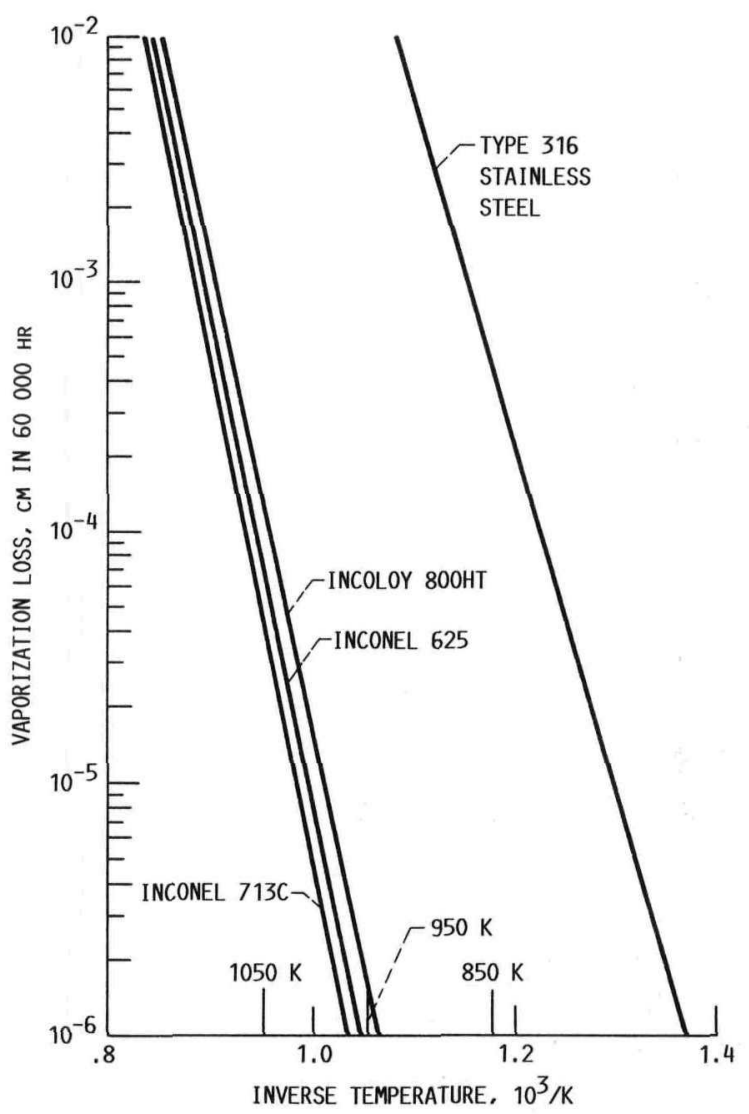

FIGURE 4. - ESTIMATED MATERIAL VAPORIZATION LOSS.

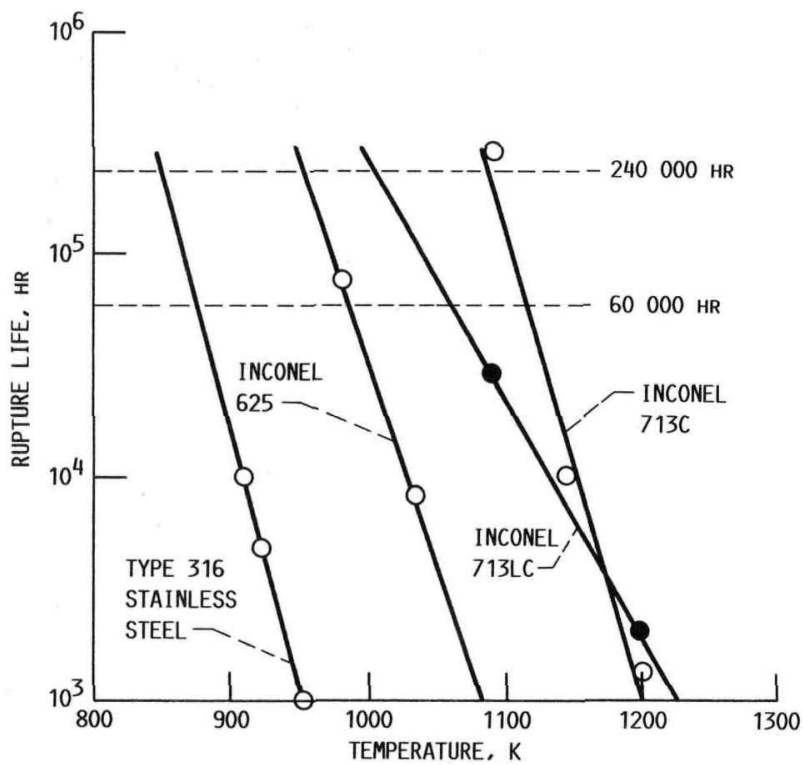

FIGURE 5. - ESTIMATED CREEP RUPTURE LIFE AT 125 MPA FOR POTENTIAL PRESSURE CONTAINMENT MATERIALS (DATA FROM REFS. 5 TO 12).

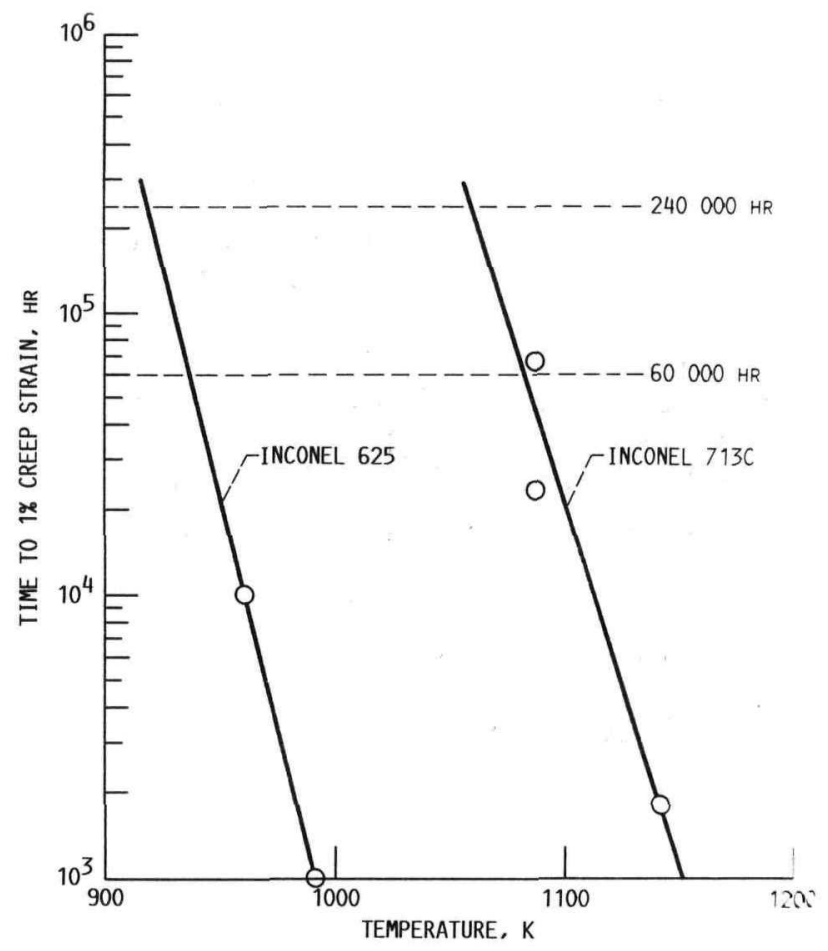

FIGURE 6. - ESTIMATED TIMES TO $1 \%$ CREEP STRAIN AT 125 MPA FOR POTENTIAL PRESSURE CONTAINMENT MATERIALS (DATA FROM REFS. 5 AND 8). 


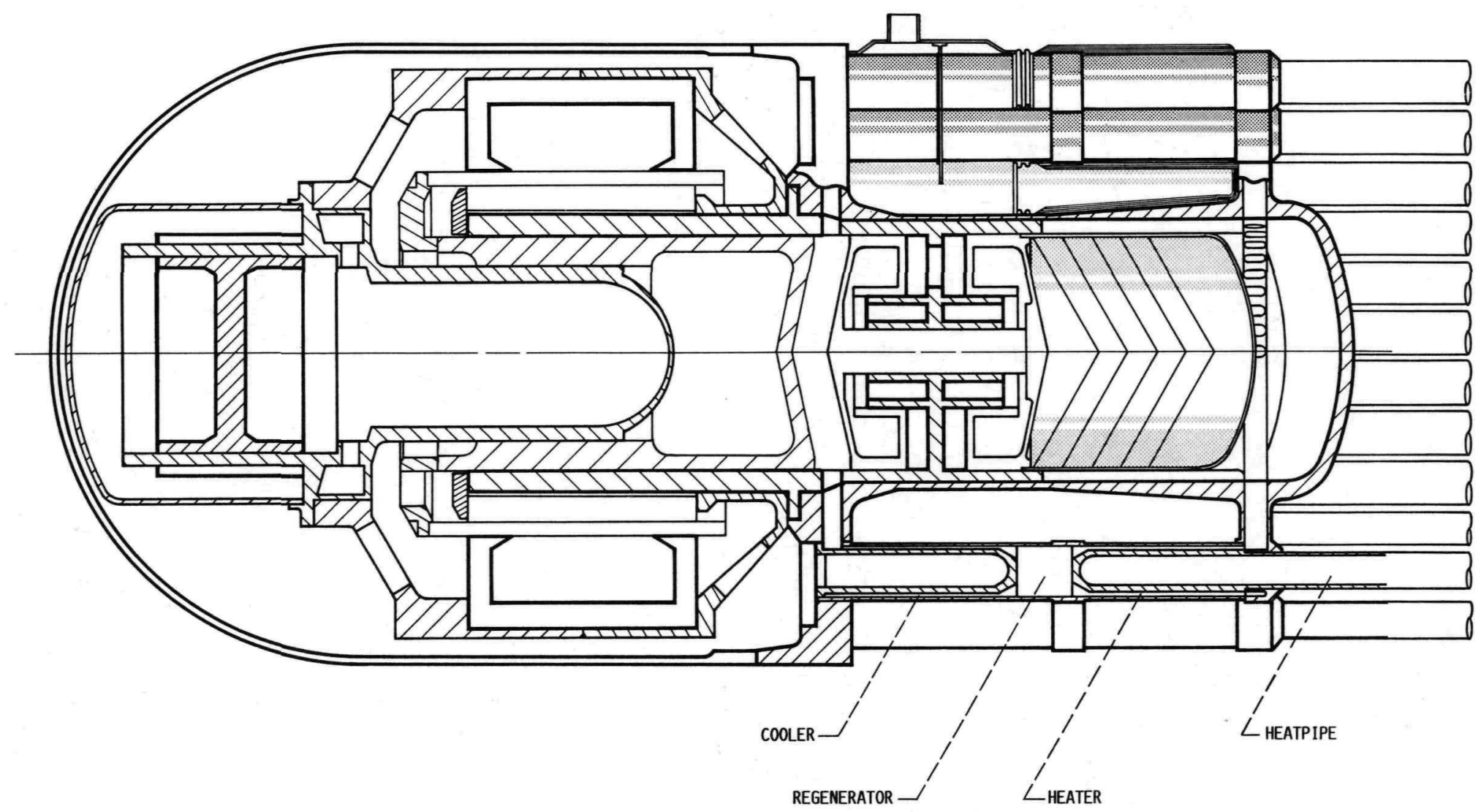

FiguRE 7. - heAT EXCHANGERS (FROM REF. 3 WITH MODIFicATION). 


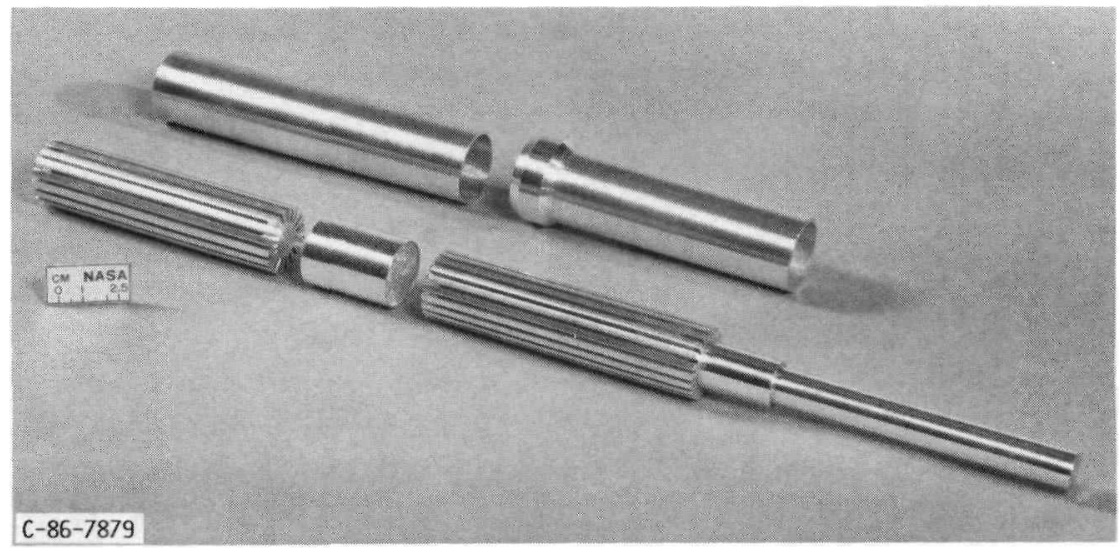

FIGURE 8. - HEAT PIPE EXCHANGER ASSEMBLY COMPONENTS.

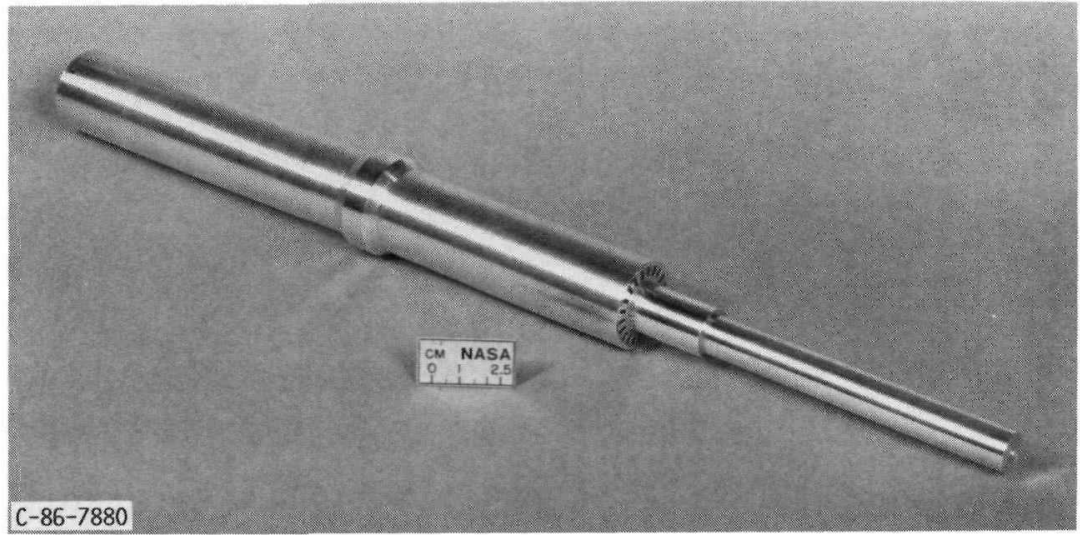

FIGURE 9. - ASSEMBLED HEAT PIPE HEAT EXCHANGER ASSEMBLY. 


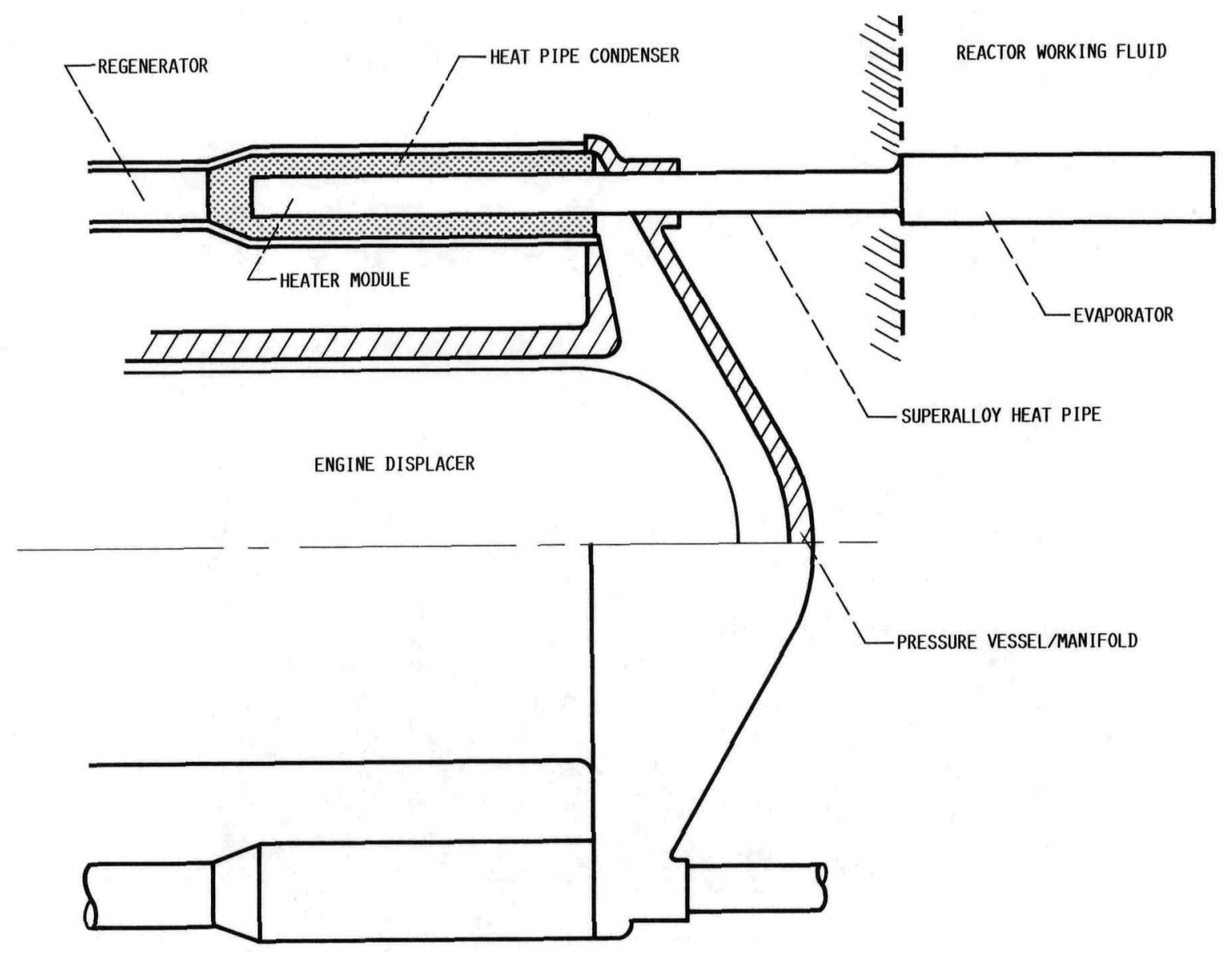

FIGURE 10. - HEAT PIPE ARRANGEMENT (FROM REF. 3). 


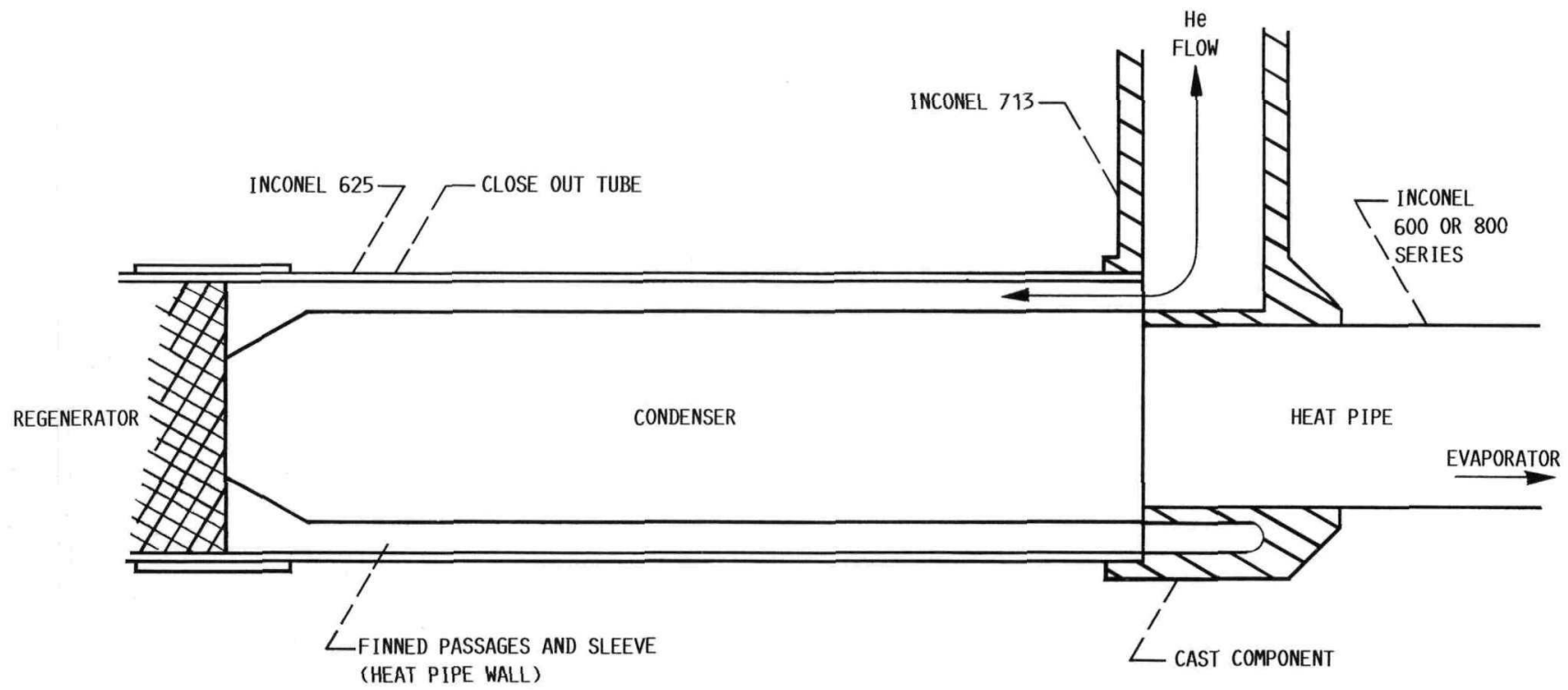

BRAZED CONFIGURATION

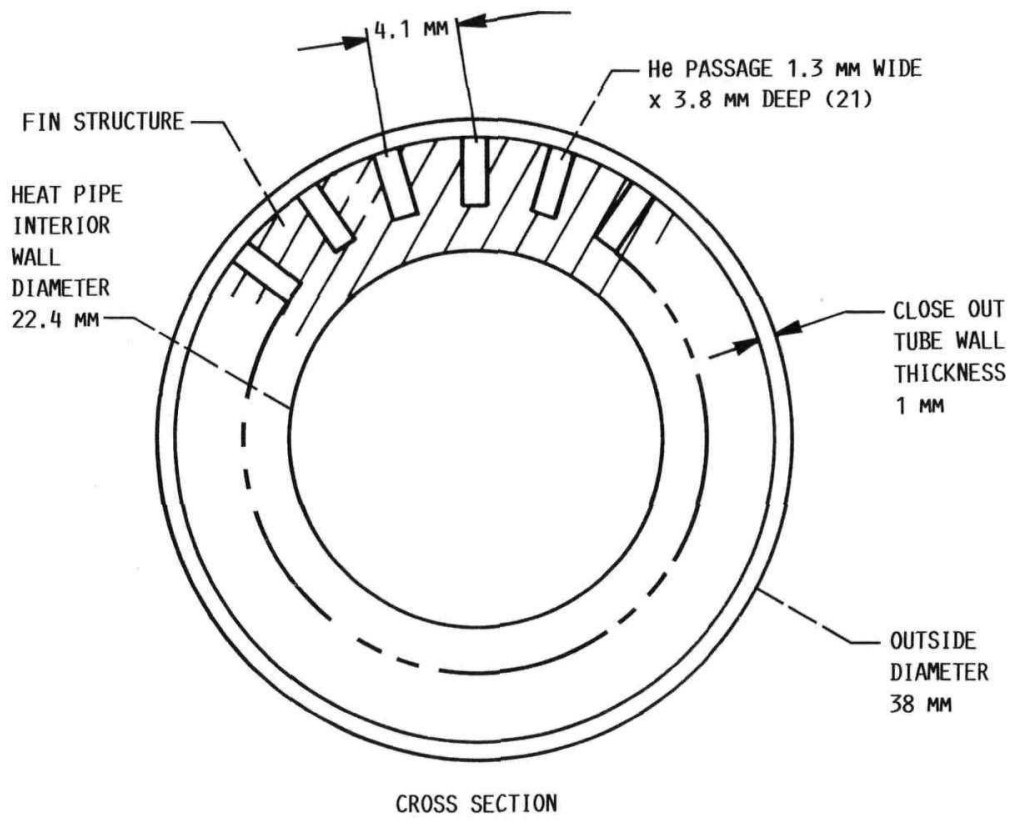

FIGURE 11. - HOT END HEAT EXCHANGER (FROM REF. 3). 

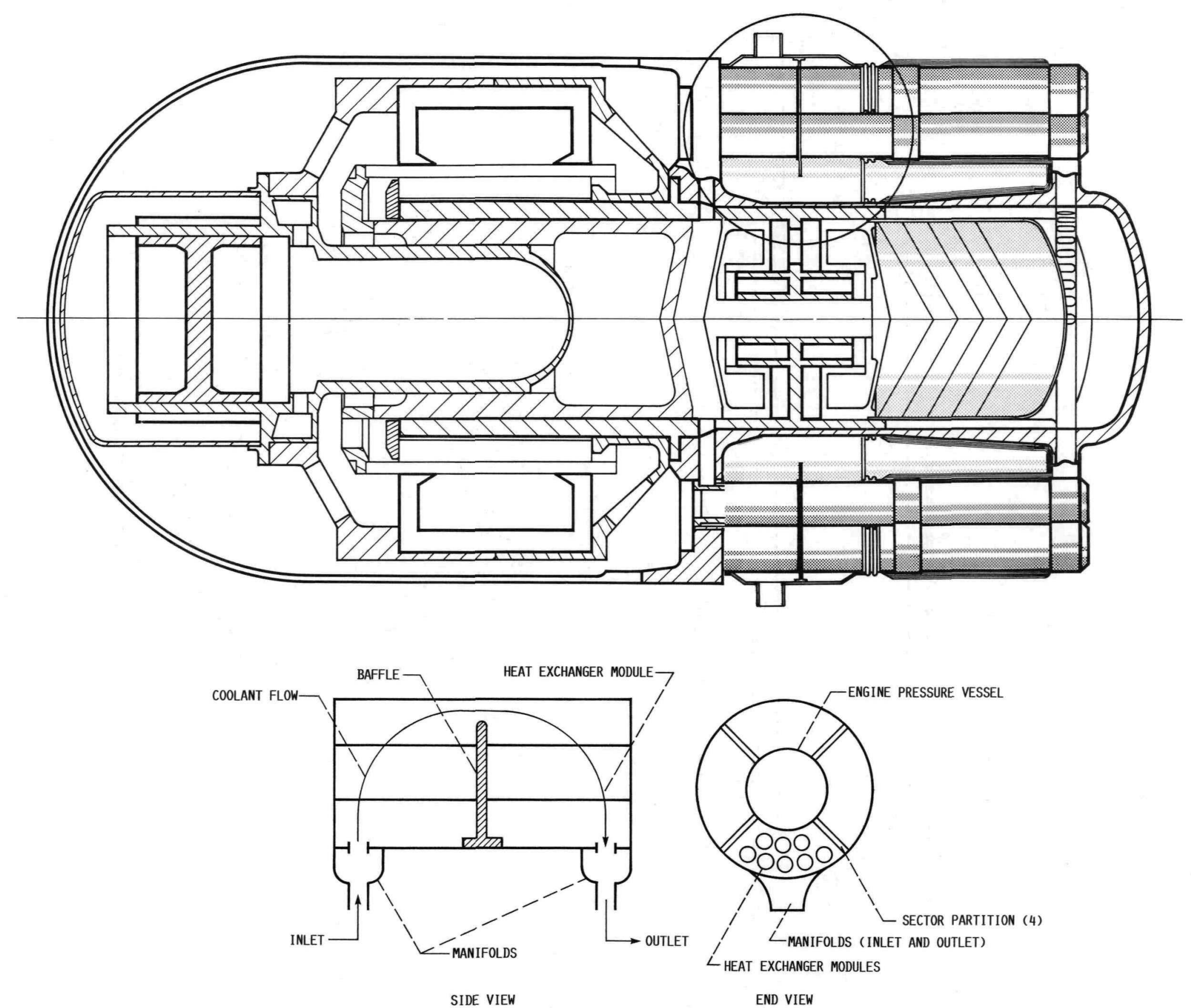

FiguRE 12. - COLD END HEAT TRANSPORT SYSTEM (FROM REF. 3 WITH MODIFICATION). 

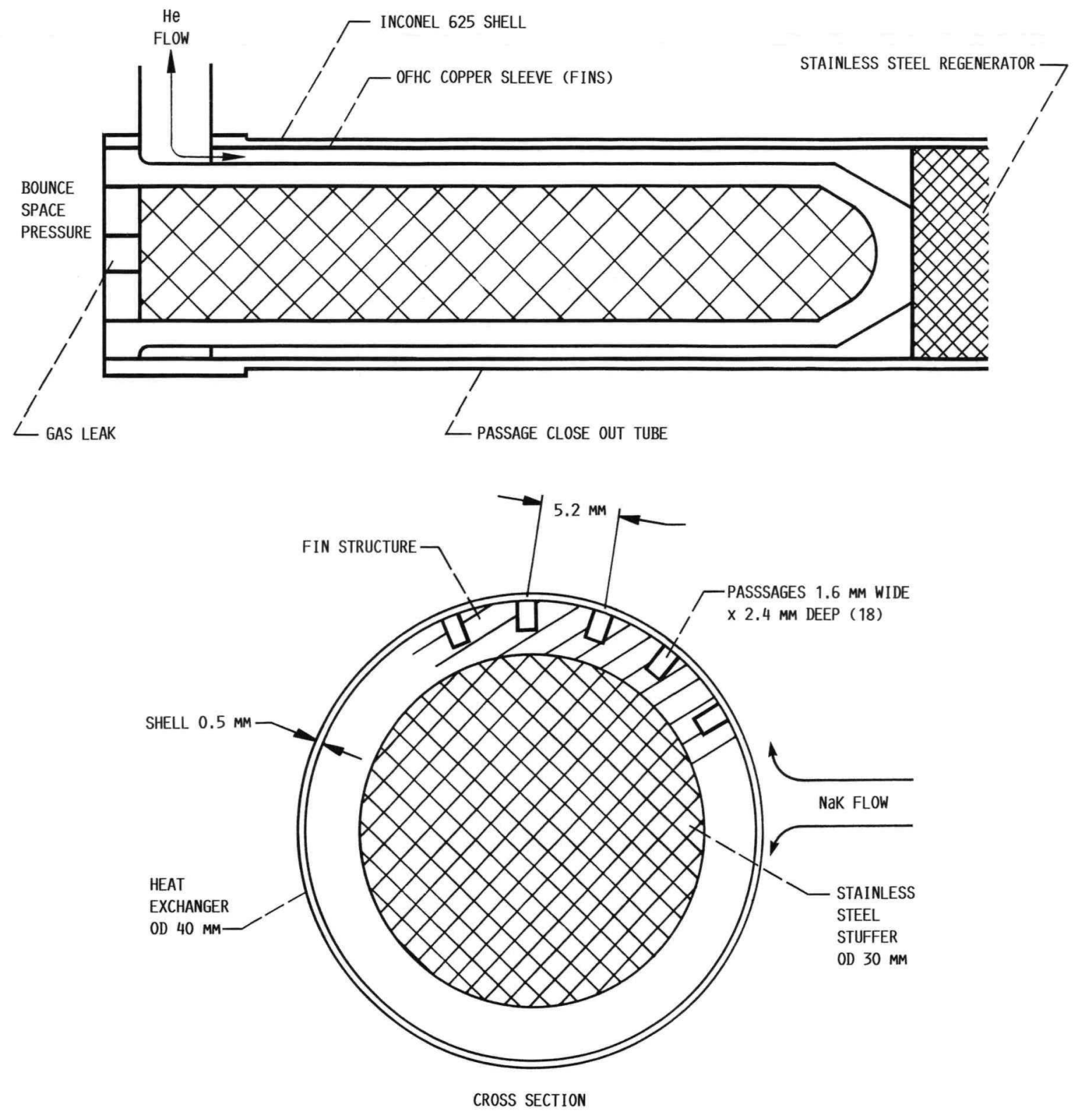

Figure 13. - COLD END heAt EXChANGER (From REF. 3 With MODification). 


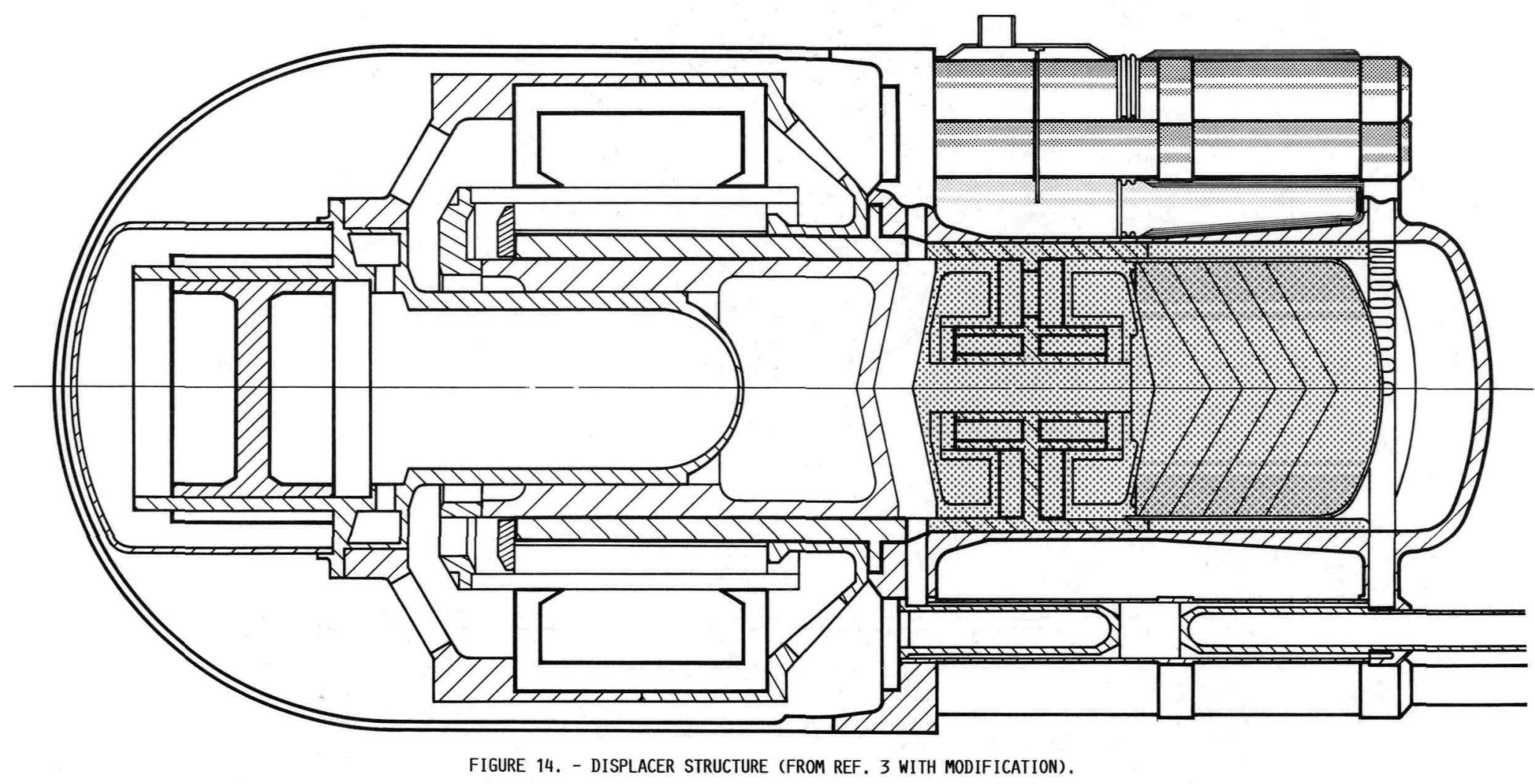




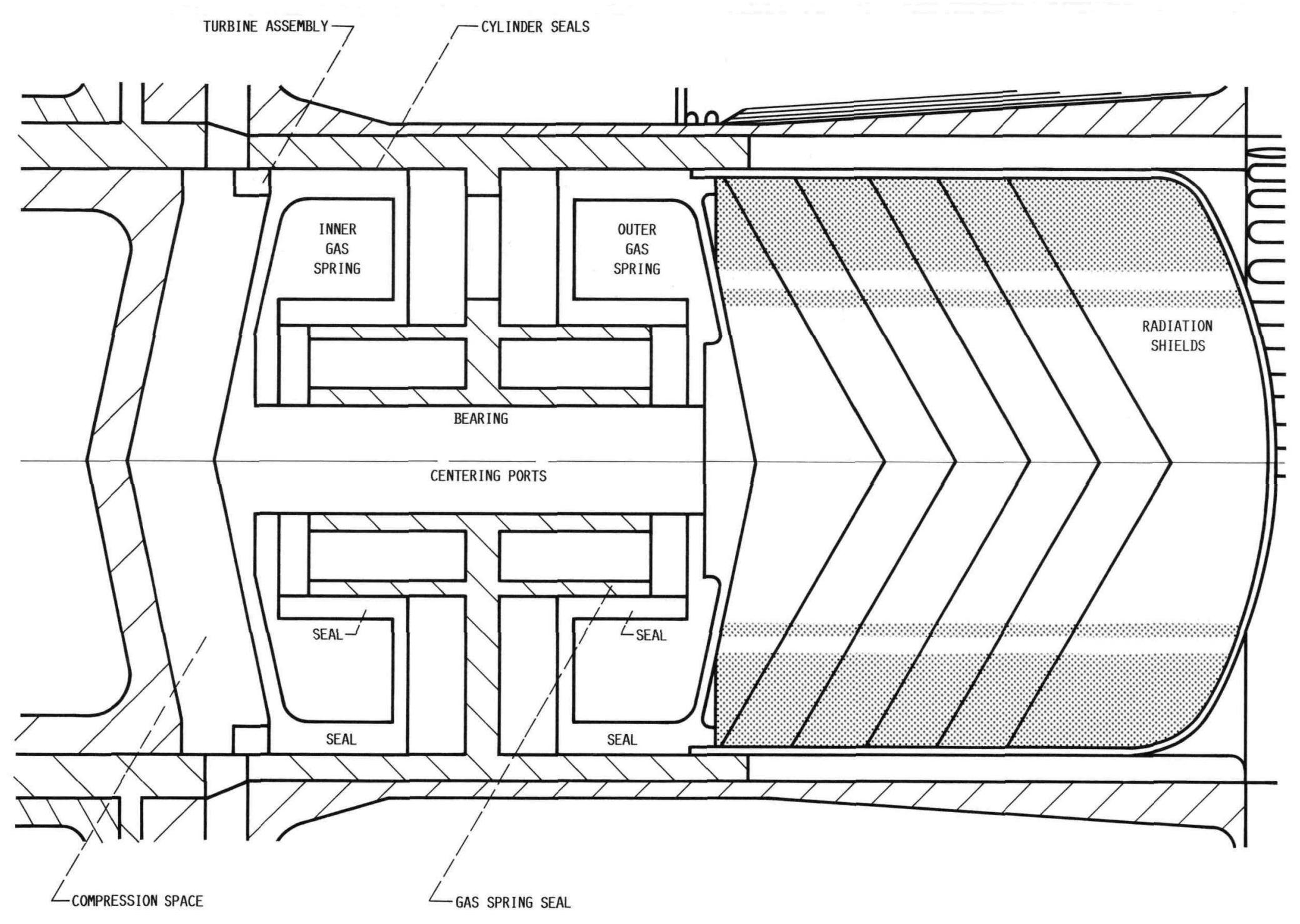

FIGURE 15. - DISPLACER MECHANICAL CONFIGURATION (FROM REF. 3). 


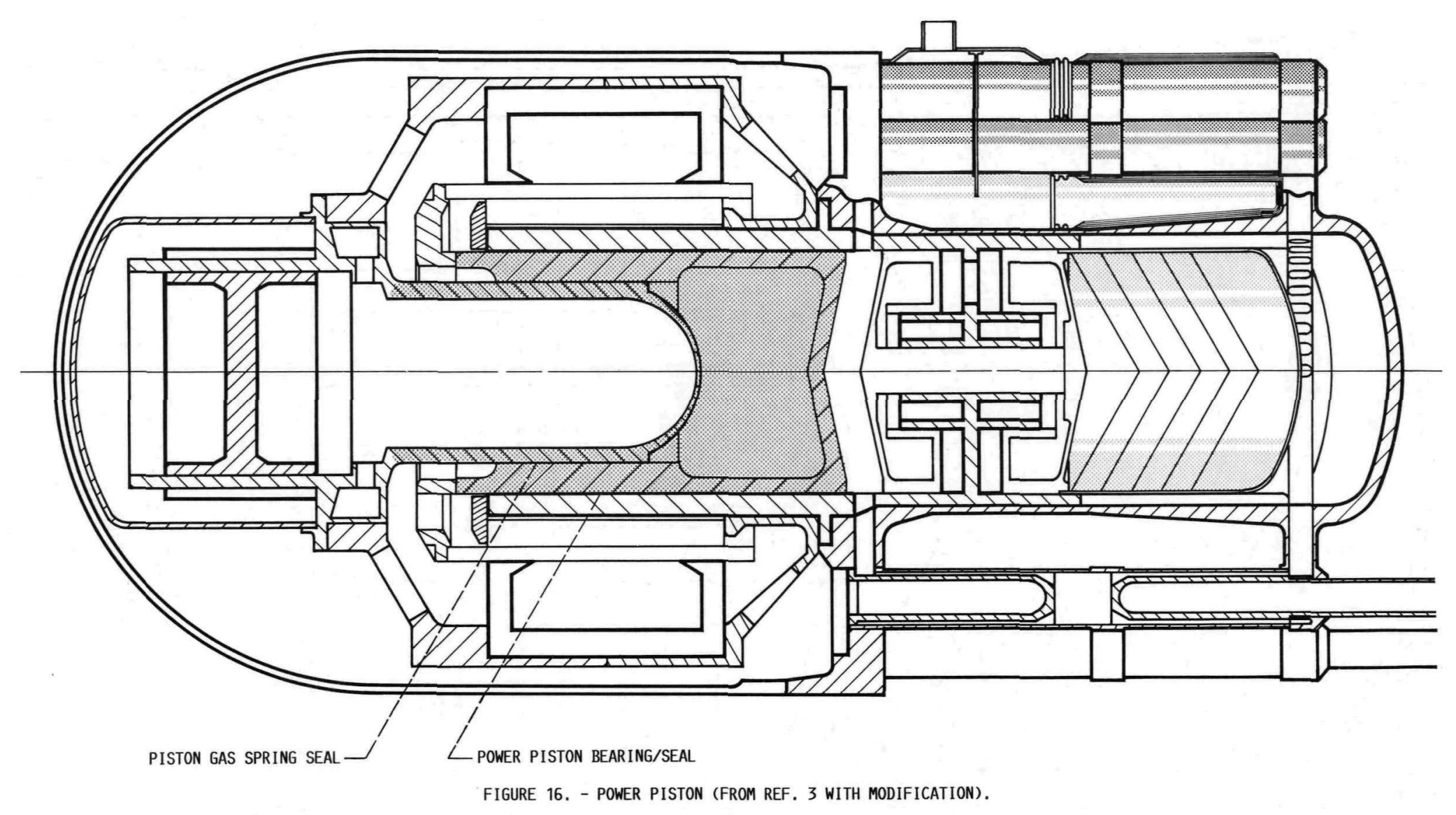




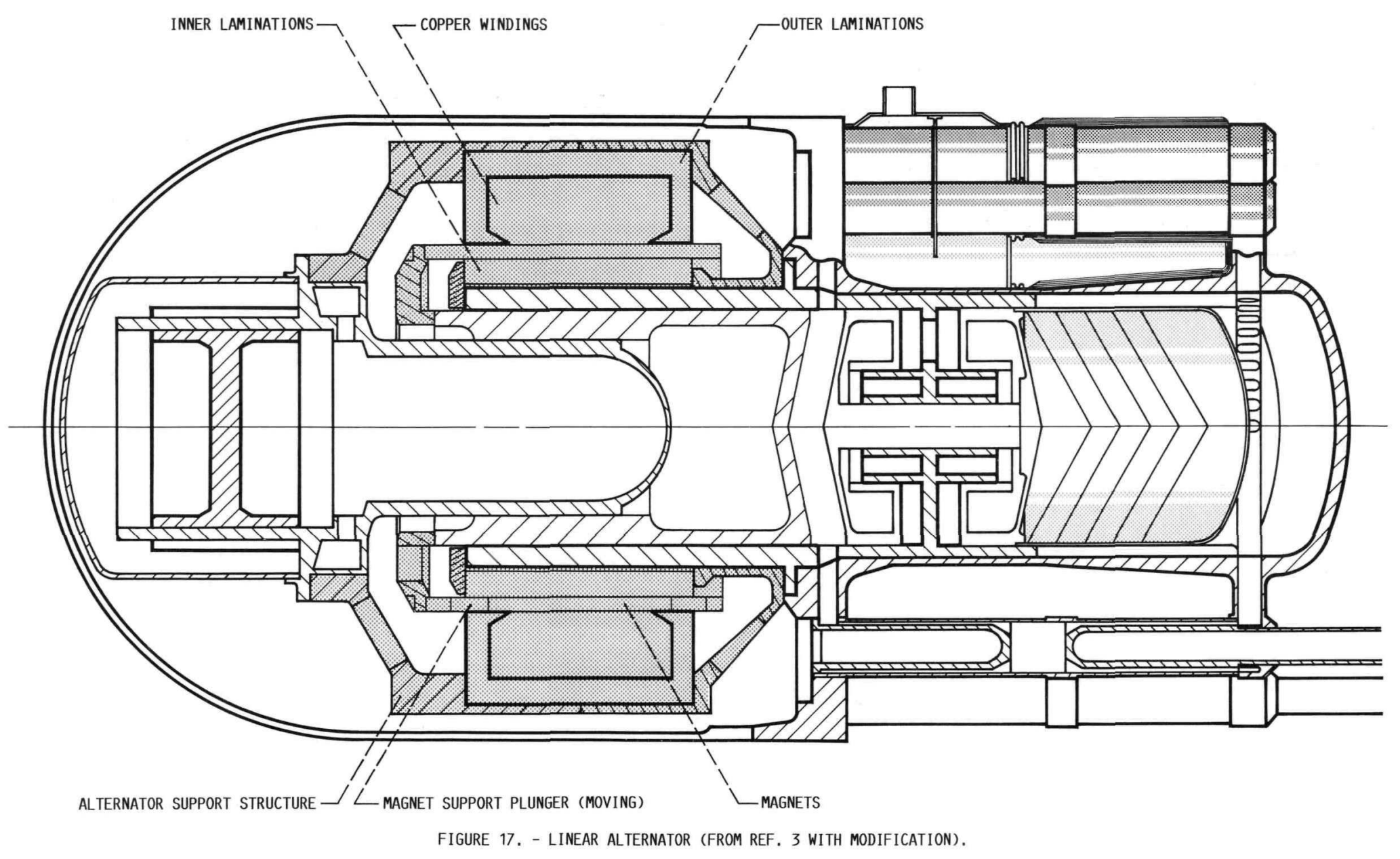




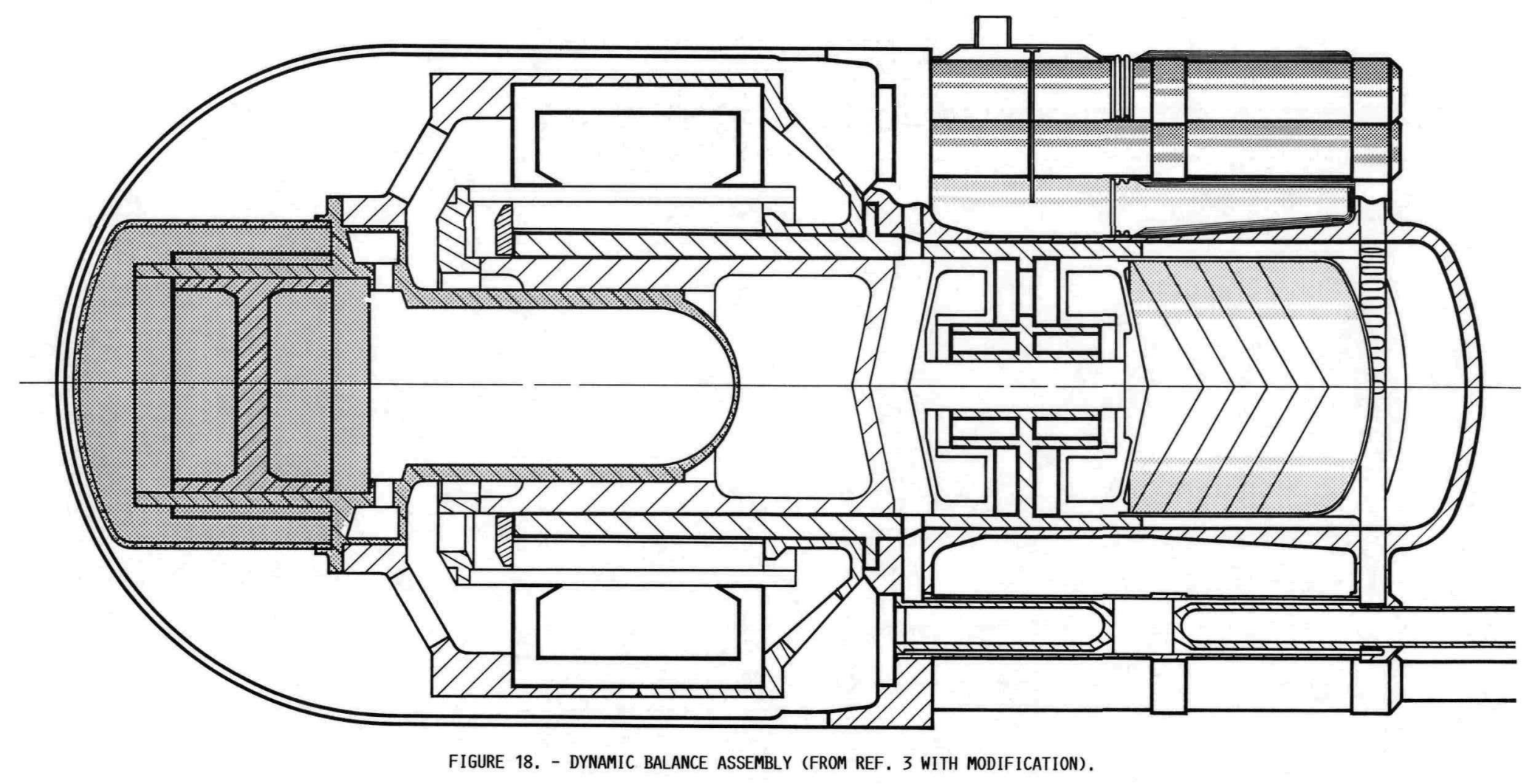




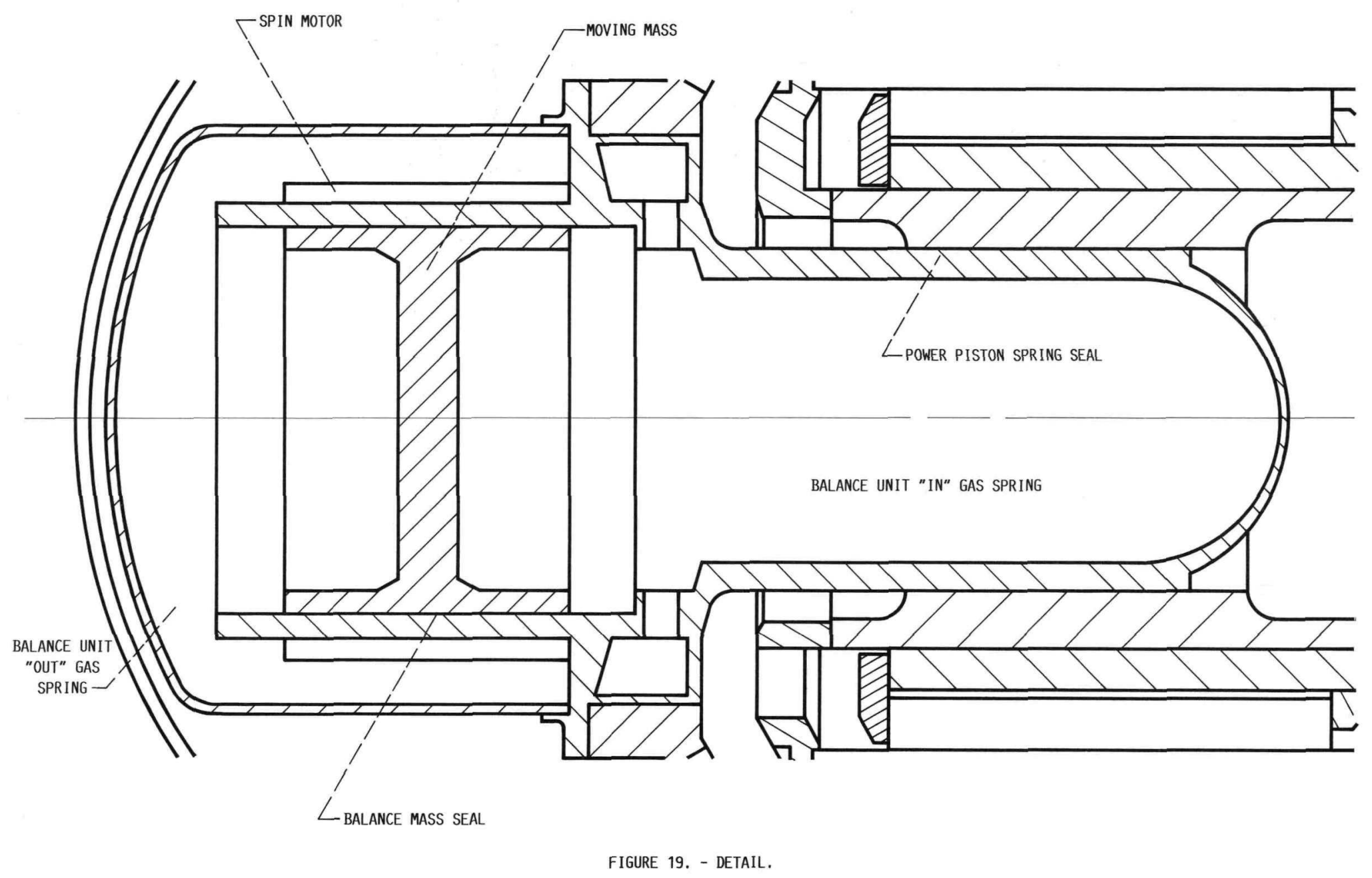




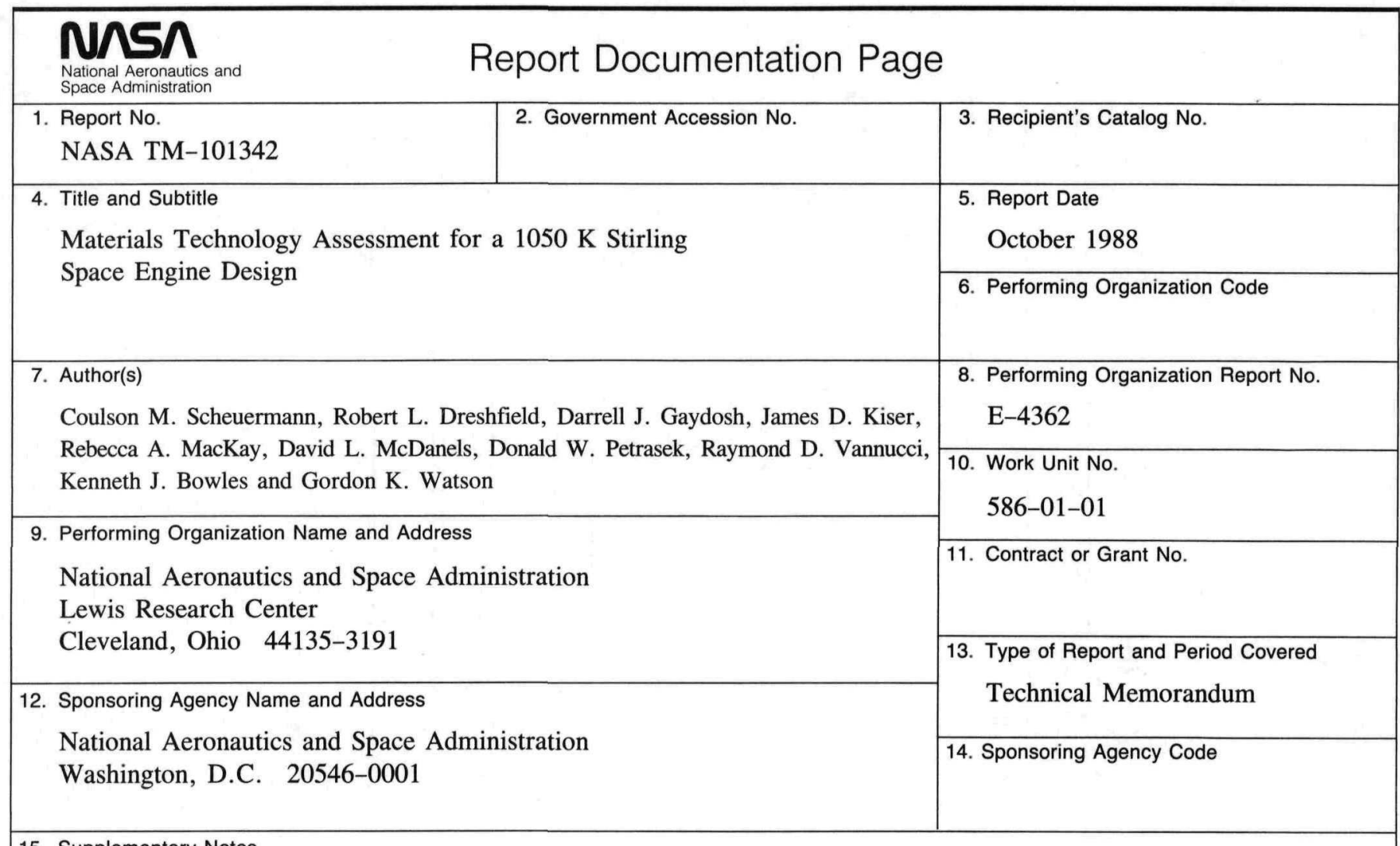

15. Supplementary Notes

16. Abstract

An assessment of materials technology and proposed materials selection was made for the $1050 \mathrm{~K}$ (superalloy) Stirling Space Engine design. The objectives of this assessment were to evaluate previously proposed materials selections, evaluate the current state-of-the-art materials, propose potential alternate materials selections and identify research and development efforts needed to provide materials that can meet the stringent system requirements. This assessment generally reaffirmed the choices made by the contractor; however, in many cases alternative choices were described and suggestions for needed materials and fabrication research and development were made.

17. Key Words (Suggested by Author(s))

Stirling engine; Auxiliary power sources; Materials; Metallic materials; Nonmetallic materials; Composite materials
18. Distribution Statement

Unclassified-Unlimited

Subject Category 23 
National Aeronautics and

Space Administration

Lewis Research Center

Cleveland, Ohio 44135

Official Business

Penalty for Private Use $\$ 300$
FOURTH CLASS MAIL

ADDRESS CORRECTION REQUESTED

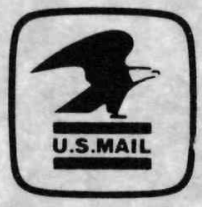

Postage and Fees Paid

Natıonal Aeronautics and

Space Administration

NASA 451 